\title{
The VAMOS Ocean-Cloud-Atmosphere-Land Study Regional Experiment (VOCALS-REx): goals, platforms, and field operations
}

\author{
R. Wood ${ }^{1}$, C. R. Mechoso ${ }^{2}$, C. S. Bretherton ${ }^{1}$, R. A. Weller ${ }^{3}$, B. Huebert ${ }^{4}$, F. Straneo ${ }^{3}$, B. A. Albrecht ${ }^{5}$, H. Coe ${ }^{6}$, \\ G. Allen ${ }^{6}$, G. Vaughan $^{6}$, P. Daum ${ }^{7}$, C. Fairall ${ }^{8}$, D. Chand ${ }^{1, *}$, L. Gallardo Klenner ${ }^{9}$, R. Garreaud ${ }^{9}$, C. Grados ${ }^{10}$, \\ D. S. Covert ${ }^{1}$, T. S. Bates ${ }^{11}$, R. Krejci ${ }^{12}$, L. M. Russell ${ }^{13}$, S. de Szoeke ${ }^{14}$, A. Brewer ${ }^{8}$, S. E. Yuter ${ }^{15}$, S. R. Springston ${ }^{7}$, \\ A. Chaigneau ${ }^{17}$, T. Toniazzo ${ }^{16}$, P. Minnis ${ }^{18}$, R. Palikonda ${ }^{23}$, S. J. Abel ${ }^{19}$, W. O. J. Brown ${ }^{20}$, S. Williams ${ }^{20}$, \\ J. Fochesatto ${ }^{21}$, J. Brioude ${ }^{22,8}$, and K. N. Bower ${ }^{6}$ \\ ${ }^{1}$ Department of Atmospheric Sciences, University of Washington, Seattle, USA \\ ${ }^{2}$ UCLA, Los Angeles, USA \\ ${ }^{3}$ Woods Hole Oceanographic Institution, USA \\ ${ }^{4}$ University of Hawai'i, Honolulu, USA \\ ${ }^{5}$ Rosenstiel School of Marine and Atmospheric Science, University of Miami, USA \\ ${ }^{6}$ School of Earth, Atmospheric and Environmental Sciences, University of Manchester, UK \\ ${ }^{7}$ Brookhaven National Laboratory, Upton, USA \\ ${ }^{8}$ NOAA Earth System Research Laboratory, Boulder, USA \\ ${ }^{9}$ Departamento de Geofisica, Universidad de Chile, Chile \\ ${ }^{10}$ Instituto del Mar del Perú, Perú \\ ${ }^{11}$ NOAA Pacific Marine Environmental Laboratory, Seattle, USA \\ ${ }^{12}$ Dept. of Applied Environmental Science (ITM), Stockholm University, Sweden \\ ${ }^{13}$ Scripps Institution of Oceanography, University of California, San Diego, USA \\ ${ }^{14}$ Oregon State University, Corvallis, USA \\ ${ }^{15}$ North Carolina State University, Raleigh, USA \\ ${ }^{16}$ Department of Meteorology, University of Reading, UK \\ ${ }^{17}$ L'Institut de Recherche pour le Développement, Marseille, France \\ ${ }^{18}$ NASA Langley Research Center, Hampton, USA \\ ${ }^{19}$ The Met Office, Exeter, UK \\ ${ }^{20}$ National Center for Atmospheric Research, Boulder, USA \\ ${ }^{21}$ University of Alaska, Fairbanks, USA \\ ${ }^{22}$ Cooperative Institute for Research in Environmental Sciences, University of Colorado, Boulder, Colorado, USA \\ ${ }^{23}$ Science Systems and Applications, Inc., Hampton, USA \\ * currently at: Pacific Northwest National Laboratory, Richland, USA
}

Received: 4 August 2010 - Published in Atmos. Chem. Phys. Discuss.: 1 September 2010

Revised: 21 December 2010 - Accepted: 29 December 2010 - Published: 21 January 2011

\begin{abstract}
The VAMOS ${ }^{1}$ Ocean-Cloud-Atmosphere-Land Study Regional Experiment (VOCALS-REx) was an international field program designed to make observations of poorly understood but critical components of the coupled climate system of the southeast Pacific. This region is characterized by strong coastal upwelling, the coolest SSTs in the tropi-
\end{abstract}

Correspondence to: R. Wood (robwood@atmos.washington.edu)

${ }^{1}$ Variability of the American Monsoon Systems, an international CLIVAR program. cal belt, and is home to the largest subtropical stratocumulus deck on Earth. The field intensive phase of VOCALSREx took place during October and November 2008 and constitutes a critical part of a broader CLIVAR program (VOCALS) designed to develop and promote scientific activities leading to improved understanding, model simulations, and predictions of the southeastern Pacific (SEP) coupled ocean-atmosphere-land system, on diurnal to interannual timescales. The other major components of VOCALS are a modeling program with a model hierarchy ranging from the local to global scales, and a suite of extended observations from regular research cruises, instrumented moorings,

Published by Copernicus Publications on behalf of the European Geosciences Union. 
and satellites. The two central themes of VOCALS-REx focus upon (a) links between aerosols, clouds and precipitation and their impacts on marine stratocumulus radiative properties, and (b) physical and chemical couplings between the upper ocean and the lower atmosphere, including the role that mesoscale ocean eddies play. A set of hypotheses designed to be tested with the combined field, monitoring and modeling work in VOCALS is presented here. A further goal of VOCALS-REx is to provide datasets for the evaluation and improvement of large-scale numerical models. VOCALSREx involved five research aircraft, two ships and two surface sites in northern Chile. We describe the instrument payloads and key mission strategies for these platforms and give a summary of the missions conducted.

\section{Introduction}

\subsection{Scientific motivation}

Interactions between the South American continent and the Southeast Pacific (SEP) Ocean are extremely important for both the regional and global climate system. Figure 1 indicates some of the key features associated with these interactions. The great height and continuity of the Andes Cordillera forms a sharp barrier to zonal flow, resulting in strong winds (coastal jet) parallel to the coasts of Chile and Peru (Garreaud and Muñoz, 2005). This, in turn, drives intense oceanic upwelling along these coasts, bringing cold, deep, nutrient/biota rich waters to the surface. As a result, the coastal SEP sea-surface temperatures (SSTs) are colder along the Chilean and Peruvian coasts than at any comparable latitude elsewhere. The cold surface, in combination with warm, dry air aloft, is ideal for the formation of marine stratocumulus clouds, and supports the largest and most persistent subtropical stratocumulus deck in the world (Klein and Hartmann, 1993). The presence of this cloud deck has a major impact upon the Earth's radiation budget by reflecting solar radiation. This helps maintain cool SSTs, resulting in tight couplings between the upper ocean and lower atmosphere in this region. The unique climate of the SEP has been very sparsely observed, yet has great economic impact, with fishing in the Humboldt Current system representing $18-20 \%$ of the worldwide marine fish catch (source: UN LME report).

It is a challenge for global and regional models to successfully simulate the SE Pacific climate system, because of its sharp horizontal and vertical gradients and the importance of subgridscale and poorly resolve physical processes. Most coupled GCMs obtain SSTs that are too warm and have too few clouds over the SEP, and show unrealistic features in the simulation of the warm tropics downstream (deSzoeke and Xie, 2008). There are major uncertainties in the representation of key physical processes in these models, which may be contributing to these errors (e.g. Mechoso et al., 1995; Ma

\section{The Southeast Pacific Climate System}

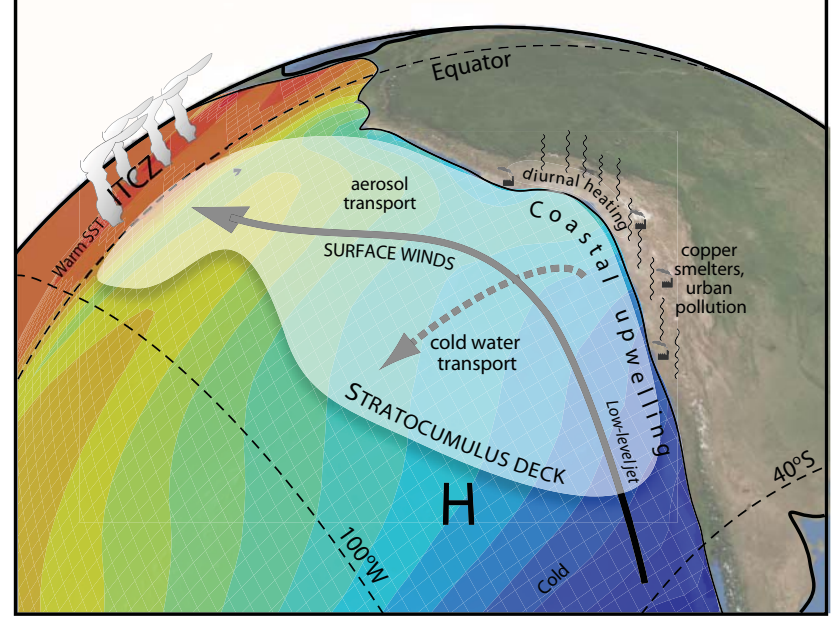

Fig. 1. Key features of the southeast Pacific (SEP) coupled climate system being explored in the VOCALS Program.

et al., 1996). The representation of stratocumulus in large scale models over the SEP is improving in some global models, but most models continue to have large biases in the location and albedo of cloud and the boundary layer vertical structure (Bretherton et al., 2004; Wyant et al., 2010). Observations are highlighting the importance of drizzle precipitation to SEP marine stratocumulus (e.g. Bretherton et al., 2004; Caldwell et al., 2005; Comstock et al., 2005), and observations and models point to a significant role for drizzle in affecting stratocumulus cloud cover and radiative properties, in particular in promoting transitions from closed to open mesoscale cellular convection (e.g. Comstock et al., 2007; Savic-Jovcic and Stevens, 2008; Wang and Feingold, 2009; Wang et al., 2010) and the formation of so-called "pockets of open cells" (POCs) (Bretherton et al., 2004; Stevens et al., 2005). Physical parameterizations currently used in large scale models do not yet attempt to represent mesoscale interactions between precipitation and cloud cover.

There is evidence that precipitation in marine stratocumulus may be influenced by anthropogenic aerosols (e.g. Geoffroy et al., 2008; Brenguier and Wood, 2009), which suggests a potential role for aerosols to influence cloud macrostructure in addition to their microphysics. Aerosol indirect effects on warm clouds remain poorly treated in large scale numerical models (e.g. Lohmann and Feichter, 2005), chiefly because the overall impact of aerosols on cloud radiative properties depends upon numerous complex small scale and mesoscale dynamical responses which result in macrophysical cloud changes (Stevens and Feingold, 2009). Satellite and research cruise data show strong gradients in aerosol and cloud microphysical properties between the near-coastal and more remote marine region of the SEP (Wood et al., 2008), making this a region where the Twomey effect may be particularly strong (see e.g. George and Wood, 2010). Since this is also 
a region where clouds are prone to drizzle (Bretherton et al., 2004; Leon et al., 2008), it is also a region potentially wellsuited to the study of aerosol-cloud interactions.

In the SEP region there are important contributions to the atmospheric aerosol from both natural and anthropogenic sources (Tomlinson et al., 2007; Hawkins et al., 2010). Cloud droplet effective radii are small off the coast of Northern Chile, implying elevated concentrations of cloud droplets (Wood et al., 2008; George and Wood, 2010; Painemal and Zuidema, 2010). These elevated concentrations are broadly downwind of major copper smelters whose combined sulfur emissions total approximately $1 \mathrm{TgS} \mathrm{yr}^{-1}$, comparable to the entire sulfur emissions from large industrialized nations such as Mexico and Germany. Offshore transport events have been shown to lead to elevated droplet concentrations offshore (Huneeus et al., 2006). However, little is actually known about the aerosol composition in the region since there have been very few measurements. We do not yet know the extent of the anthropogenic influence, nor do we fully understand the complex chemistry occurring in the pristine boundary layer further offshore.

In the absence of cloud macrophysical responses, the reduced droplet effective radii resulting from increased concentrations of cloud droplets would increase the reflected solar radiation, and estimates of the component of the reflected shortwave radiation due to geographic variability in effective radius alone are $\sim 10-20 \mathrm{~W} \mathrm{~m}^{-2}$ or $20-40 \%$ of the mean reflected shortwave (George and Wood, 2010). The magnitude of these estimates is such that the indirect effects of aerosols on clouds could lead to significant decreases in the amount of solar radiation entering the ocean, with significant implications for the ocean heat budget. However, we do not yet fully understand the controls on cloud droplet concentration in the MBL, and it is possible that meteorological controls (e.g. precipitation sinks) in addition to aerosol sources may play a significant role. Further, we are beginning to understand that cloud responses to aerosols are not solely due to the Twomey effect alone, and that fast feedbacks can both enhance and counteract the Twomey effect (e.g. Ackerman et al., 2004; Xue et al., 2008).

Early estimates of surface heat fluxes from climatologies and numerical weather prediction models showed diverse conclusions as to whether or not the offshore ocean gained from or lost heat to the atmosphere. Observations from deployment of the IMET surface mooring beginning in 2000 near the location of the annual maximum in stratus cloud cover showed that the ocean gains about $40 \mathrm{~W} \mathrm{~m}^{-2}$ annually and was subject to over $1 \mathrm{~m}$ in evaporation (Colbo and Weller, 2007; deSzoeke et al., 2010). This surface forcing was applied to a relatively thin ocean surface mixed layer (annual maximum thickness of about $150 \mathrm{~m}$ ) that lies over a relatively cold, fresh water mass formed to the south. For oceanographers, the challenge is to understand how the shallow ocean surface layer under the clouds maintains its temperature and salinity under this surface forcing.
Studies of the upper ocean heat budget offshore of the coastal upwelling zone indicate weak mean advection, energetic eddies, and the need for a source of relatively cold, fresh water (Colbo and Weller, 2007). This divergence of heat and salt is presumably achieved by the interaction of mesoscale and submesoscale processes with the surface layer, though the precise mechanisms are presently unclear. Candidates include oceanic eddies advecting relatively cold, fresh anomalies westward from the coastal zone and vertical mixing processes transporting heat and salt downward, across the base of the oceanic mixed layer. In general, however, little is know about the oceanic eddy processes in the SEP, not only regarding their role in influencing the mixed layer properties but also their potential role in modulating the concentration of aerosol precursors such as dimethylsulfide and complex organic species.

Clouds over the SEP exhibit a much stronger diurnal cycle of cloud cover and liquid water path, LWP (Rozendaal et al., 1995; Wood et al., 2002) than MBL clouds at comparable latitudes in the Northern Hemisphere. Regional model simulations (Garreaud and Muñoz, 2004) suggest that a large-scale diurnal subsidence wave formed by the interaction of the coastal jet along the Chilean coast with dry convective heating over the western Andean slopes travels at least $1000 \mathrm{~km}$ over the SEP and leads to a strong diurnal cycle of subsidence at remote locations. Using improved observations of how this wave influences the diurnal cycle of marine stratocumulus should be useful for assessing whether the diurnal variations of clouds in large scale models are well represented.

\subsection{Motivation for the VOCALS regional experiment}

The science issues described above are central to VOCALS (VAMOS Ocean-Cloud-Atmosphere-Land Study), an international CLIVAR program to develop and promote scientific activities leading to improved understanding, model simulations, and predictions of the southeastern Pacific (SEP) coupled ocean-atmosphere-land system, on diurnal to interannual timescales. VOCALS is ultimately driven by a need for improved numerical model simulations of the coupled climate system in both the SEP and over the wider tropics and subtropics. At the root of VOCALS's approach to the problem is the premise that its solution requires a synergy between numerical modeling, field studies, and extended observations such as buoys and satellites. With this in mind, the VOCALS Regional Experiment (VOCALS-REx) was conceived. In this manuscript we present an overview of the hypotheses, instrumentation, sampling platforms, sampling strategies, and missions conducted in pursuit of the science goals. We deliberately do not discuss any scientific results from REx; this paper is intended as a background framework and a supplement to the numerous other papers which present those results. 
Table 1. The VOCALS Hypotheses.

\begin{tabular}{|c|c|}
\hline H1a & $\begin{array}{l}\text { 1. AEROSOL-CLOUD-DRIZZLE HYPOTHESES } \\
\text { Variability in the physicochemical properties of aerosols has a measurable impact upon the formation of drizzle in } \\
\text { stratocumulus clouds over the SEP. }\end{array}$ \\
\hline $\mathrm{H} 1 \mathrm{~b}$ & $\begin{array}{l}\text { Precipitation is a necessary condition for the formation and maintenance of pockets of open cells (POCs) within } \\
\text { stratocumulus clouds. }\end{array}$ \\
\hline H1c & $\begin{array}{l}\text { The small effective radii measured from space in the coastal region of over the SEP are primarily controlled by an- } \\
\text { thropogenic, rather than natural, aerosol production, and entrainment of polluted air from the lower free-troposphere } \\
\text { is an important source of cloud condensation nuclei }(\mathrm{CCN}) \text {. }\end{array}$ \\
\hline H1d & Depletion of aerosols by coalescence scavenging is necessary for the maintenance of POCs. \\
\hline & 2. COUPLED OCEAN-ATMOSPHERE HYPOTHESES \\
\hline $\mathrm{H} 2 \mathrm{a}$ & $\begin{array}{l}\text { Improvement of CGCMs performance in the SEP is key to the successful simulation of the ITCZ/SPCZ, complex, } \\
\text { which will also benefit simulation of other regions. A significant improvement can be achieved through better } \\
\text { representing the effects of stratocumulus clouds on the underlying surface fluxes and those of oceanic mesoscale } \\
\text { eddies in the transport of heat. }\end{array}$ \\
\hline $\mathrm{H} 2 \mathrm{~b}$ & $\begin{array}{l}\text { Oceanic mesoscale eddies play a major role in the transport of relatively fresh water from the coastal upwelling } \\
\text { region and in the production of sea-water and atmospheric DMS in the coastal and offshore regions. Upwelling, by } \\
\text { changing the physical and chemical properties of the upper ocean, has a systematic and noticeable effect on aerosol } \\
\text { precursor gases and the aerosol size distribution in the MBL over the SEP. }\end{array}$ \\
\hline $\mathrm{H} 2 \mathrm{c}$ & $\begin{array}{l}\text { The diurnal subsidence wave ("upsidence wave") originating in northern Chile/southern Peru has an impact upon } \\
\text { the diurnal cycle of clouds that is well-represented in numerical models. }\end{array}$ \\
\hline $\mathrm{H} 2 \mathrm{~d}$ & $\begin{array}{l}\text { The entrainment of relatively cool fresh intermediate water from below the surface layer during mixing associated } \\
\text { with energetic near-inertial oscillations generated by transients in the magnitude of the trade winds is an important } \\
\text { process to maintain heat and salt balance of the surface layer of the ocean in the SEP. }\end{array}$ \\
\hline
\end{tabular}

In Sect. 6, we will briefly summarize the VOCALS strategy for coordinating modeling work with REx (again, without presenting results). REx was designed to inform improvement of both global and regional climate and chemical transport models and also process-level models such as large-eddy simulations of aerosol-cloud interaction. In addition, REx made use of real-time output from several models for mission planning.

VOCALS-REx provided intensive observations of key processes contributing to the climate of the SEP. The observations are being used to help test a coordinated set of hypotheses presented in Table 1, to evaluate our ability to model the important physical and chemical processes in the SEP, and to help evaluate the performance of satellite retrievals. The VOCALS-REx hypotheses are organized into two broad themes: (1) the impacts of aerosols upon the microphysical and structural properties of stratocumulus clouds and drizzle production; (2) the coupled ocean-atmosphere-land system.

\section{VOCALS-REx study region and dates}

VOCALS-REx took place during October and November 2008, engaging over 150 scientists from 40 institutions in 8 nations. A variety of operations within a limited domain of the SEP coupled climate system were conducted (Fig. 2). REx operations took place in the domain $69-86^{\circ} \mathrm{W}, 12-$ $31^{\circ} \mathrm{S}$, with a concentration of sampling close to the $20^{\circ} \mathrm{S}$ latitude line. This parallel was chosen as it transects the heart of the SEP stratocumulus sheet (Klein and Hartmann, 1993; George and Wood, 2010), exhibits strong longitudinal microphysical contrasts (Bennartz, 2007; Wood et al., 2008; George and Wood, 2010; Bretherton et al., 2010), crosses a region where open cell formation is frequently observed (Wood et al., 2008), and is impacted by mesoscale ocean eddies (e.g. Colbo and Weller, 2007; Toniazzo et al., 2009).

Overall, the VOCALS-REx period was characterized by near climatological atmospheric conditions off northern Chile and southern Peru (Toniazzo et al., 2011). However, significant variations in MBL depth occurred during October when midlatitude troughs reached the VOCALS region leading to four episodes (1-2 day long) of mid-tropospheric upward motion. In contrast, November exhibited less synoptic 


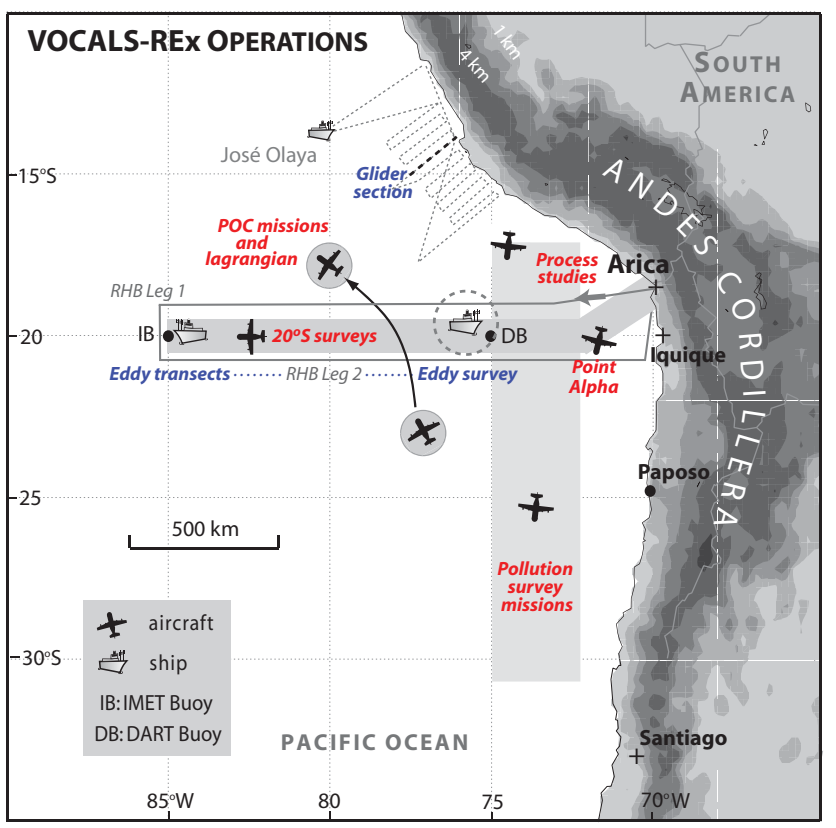

Fig. 2. VOCALS REx study region showing main sampling platforms and mission types. The land aerosol/meteorology site at $\mathrm{Pa}$ poso, the sounding station at Iquique, and the instrumented IMET and DART buoys are also shown.

forcing and almost continuous subsidence (Rahn and Garreaud, 2010b; Toniazzo et al., 2011).

In the following sections we first discuss the research platforms and the instrumentation used to make observations during VOCALS-REx, followed by the chief mission types and sampling strategy.

\section{Platforms and instrumentation}

A total of five aircraft (NSF/NCAR C-130, the DoE G-1, the CIRPAS Twin Otter, the FAAM BAe-146, and the NERC Dornier 228, see Table 2) two research vessels (the NOAA R/V Ronald H. Brown, RHB, and the Peruvian IMARPE José Olaya, see Tables 3 and 4 respectively) sampled the lower atmosphere and upper-ocean during REx. These mobile platforms were complemented by a number of groundbased observational sites (Table 5).

\subsection{Aircraft platforms}

Three of the aircraft deployed in VOCALS-REx (C-130, G-1 and Twin Otter) were operational from 14 October to 15 November 2008, with the other two aircraft (BAe-146 and Do-228) operational from 26 October-15 November 2008. Table 2 shows the dates over which missions were flown, and Fig. 3 provides a graphical representation of the aircraft sampling as a function of day and longitude. Tables describing the specific aircraft missions are discussed below. The air- craft measurements are designed to critically address several of the VOCALS hypotheses (Table 1), particularly those related to aerosol-cloud-drizzle interactions and those involving the sources and sinks of atmospheric aerosols.

\subsubsection{NSF/NCAR Lockheed C-130}

The NSF/NCAR C-130Q is operated by the Research Aviation Facility (RAF) at the National Center for Atmospheric Research (NCAR) in the United States. During REx the C-130 flew missions up to $9 \mathrm{~h}$ in duration reaching $1600 \mathrm{~km}$ offshore, making it the longest range aircraft used in REx. The C-130 has a large payload and carries instruments and sensors in pods and pylons on both wings. Details of the instrumentation payload on the C130 are given in Table 2. The aircraft is flown at an airspeed of approximately $100 \mathrm{~m} \mathrm{~s}^{-1}$ for boundary layer sampling. Details of the missions flown in REx are given in Table 6. Further information on the instrumentation on the C-130 including data quality can be found online at http://www.eol.ucar.edu/about/our-organization/raf/ data/vocals/vocals-documentation-summary.

\subsubsection{FAAM BAe-146}

The Facility for Airborne Atmospheric Measurements (FAAM) BAe-146 aircraft is operated by a joint agreement between the Met Office and the Natural Environment Research Council (NERC) in the United Kingdom. The BAe146 served as the medium range aircraft operated in REx, flying missions of typically 5 hours and sampling up to $900 \mathrm{~km}$ offshore. The BAe-146 has a large payload and carries instruments and sensors in pods and pylons on both wings. Details of the instrumentation payload on the BAe146 are given in Table 2. The aircraft is flown at an airspeed of approximately $100 \mathrm{~m} \mathrm{~s}^{-1}$ for boundary layer sampling. Details of the missions flown in REx are given in Table 7. Further information on the instrumentation on the BAe-146 including data quality can be found online at http: //data.cas.manchester.ac.uk/vocals/vocals-uk-summary.pdf.

\subsubsection{DoE Gulfstream-1 (G-1)}

The Department of Energy Gulfstream-1 (G-1) is operated by the Research Aircraft Facility (RAF) at the Pacific Northwest National Laboratory in the United States. The G-1 served as a medium range aircraft in REx, with sampling out to $800 \mathrm{~km}$ from the coast. The aircraft is flown at an airspeed of approximately $100 \mathrm{~m} \mathrm{~s}^{-1}$ for boundary layer sampling. Details of the instrumentation payload on the G-1 are given in Table 2 . Details of the missions flown in REx are given in Table 8.

The NERC Dornier-228 is operated by the Airborne Research and Survey Facility (ARSF) of the Natural Environment Research Council (NERC) in the United Kingdom. Its main role in VOCALS-REx was remote sensing of clouds out 
Table 2. Details of the aircraft used in VOCALS-REx.

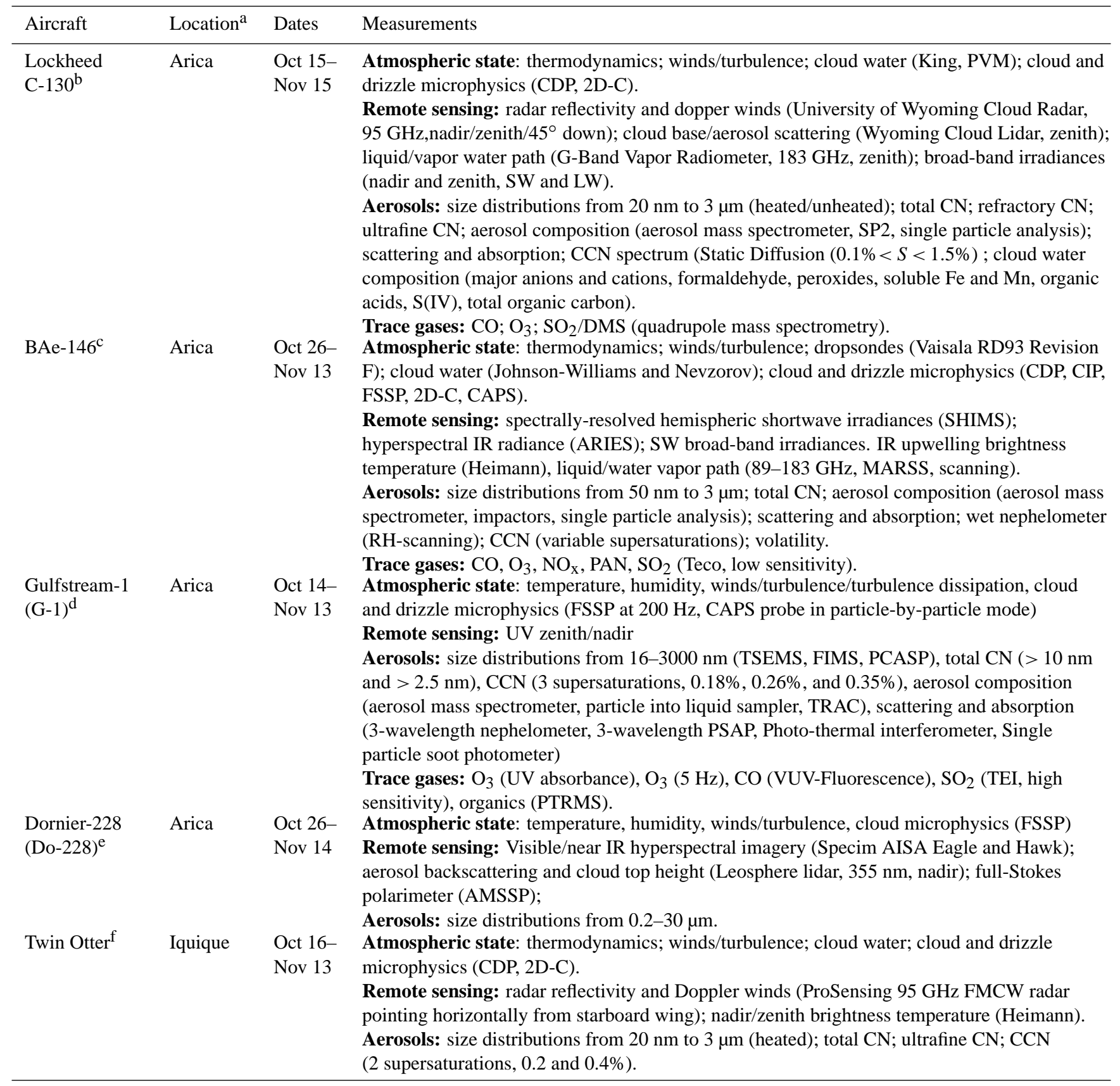

\footnotetext{
a See map, Fig. 2 .

b Operated by the National Center for Atmospheric Research and funded by the US National Science Foundation.

c Operated by the Facility for Airborne Atmospheric Measurements (FAAM), funded jointly by The Met Office and the Natural Environment Research Council in the UK.

${ }^{\mathrm{d}}$ Operated by the Research Aircraft Facility at the Pacific Northwest National Laboratory and supported by the US Department of Energy (DoE).

e Operated by the Airborne Remote Sensing facility of the Natural Environment Research Council, UK.

f Operated by the Center for Interdisciplinary Remotely-Piloted Aircraft Studies (CIRPAS) and supported by the US Office of Naval Research (ONR).
}

to $76^{\circ} \mathrm{W}$, using lidar, a hyperspectral imager and polarimeter. Details of the instrumentation payload on the Do-228 are given in Table 2. Details of the missions flown in REx are given in Table 9. Most flights took place at an altitude of $4-5 \mathrm{~km}$, with the remainder profiling the free troposphere to measure in-situ aerosol concentration. Typically, the Dornier 
Table 3. Details of the Ronald H. Brown (RHB) measurements in VOCALS-REx.

\begin{tabular}{|c|c|}
\hline Location ${ }^{\mathrm{a}} / \mathrm{Dates}$ & Measurements \\
\hline \multirow{6}{*}{$\begin{array}{l}\text { R/V Ronald H. Brown } \\
\text { See map Fig. } 9 \\
\text { Oct } 25 \text {-Dec } 2\end{array}$} & Atmospheric state: temperature, humidity, winds (flux tower), cloud observations and photography \\
\hline & Upper air: $6 \times$ daily radiosonde (Vaisala RS92) launches. \\
\hline & $\begin{array}{l}\text { Remote sensing: C-band radar reflectivity and Doppler winds within drizzle (3-d volumetric and } \\
\text { range-height scans every } 3 \mathrm{~min}, 60 \mathrm{~km} \text { range); W-band radar reflectivity profiles and Doppler velocity for } \\
\text { cloud/drizzle (vertically pointing } 95 \mathrm{GHz} \text { cloud radar); cloud base and drizzle backscatter (lidar } \\
\text { ceilometer); volumetric lidar backscatter and winds (scanning High Resolution Doppler Lidar, also } \\
\text { operated in vertically pointing mode, } 6 \mathrm{~km} \text { range); liquid water path and water vapor path } \\
\text { (23/31/90/183 GHz microwave radiometers); broad band irradiances. }\end{array}$ \\
\hline & $\begin{array}{l}\text { Aerosols: size distributions from } 20 \mathrm{~nm} \text { to } 10 \mu \mathrm{m} \text { diameter; } \mathrm{CN}(>12 \mathrm{~nm}) \text {; ultrafine } \mathrm{CN} \text { ( }>3 \mathrm{~nm} \text { ), aerosol } \\
\text { mass and composition (Aerosol Mass Spectroscopy } 80-800 \mathrm{~nm} \text {, super- and sub-micron impactors for ion } \\
\text { and gravimetric mass analysis, } 7 \text {-stage impactor for ion composition, single particle analysis, submicron } \\
\text { FTIR for organic functional groups and mass, single particle STXM-NEXAFS and SEM-EDX analysis); } \\
\text { super- and sub-micron scattering and absorption coefficients at three visible wavelengths; CCN spectrum } \\
\text { ( } 5 \text { supersaturations, } 0.10 .15,0.2 \text {, and } 0.3 \text {, and } 0.6 \% \text { ); aerosol volatility at } 230 \mathrm{C} \text { for } 20-800 \mathrm{~nm} \text { size } \\
\text { interval; aerosol profiling (differential absorption spectroscopy, MAX-DOAS) }\end{array}$ \\
\hline & $\begin{array}{l}\text { Trace gases: Radon }\left({ }^{222} \mathrm{Rn}\right) ; \mathrm{O}_{3} \text {; atmospheric DMS (quadrupole mass spectrometry); seawater } \\
\text { DMS/DMSP, chlorophyll-a, and dissolved } \mathrm{CO}_{2} \text {; reactive trace gases (differential absorption spectroscopy, } \\
\text { MAX-DOAS) }\end{array}$ \\
\hline & $\begin{array}{l}\text { Oceanography: } 438 \text { Underway CTD profiles (temperature, conductivity, pressure) to between } 200 \text { and } \\
800 \mathrm{~m} \text { depth, horizontal spacing from } 1-30 \mathrm{~km} ; 35 \mathrm{CTD} \text { profiles to } 2500 \mathrm{~m} \text { in and outside of eddies/fronts } \\
\text { with associated water sampling for the collection of nutrients, salinity and oxygen samples; } 10 \mathrm{SOLO} \\
\text { profiling floats deployed with dissolved oxygen sensors; underway sea-surface salinity/temperature } \\
\text { measurements; } 19 \text { surface drifters; } 15 \text { Vertical microstructure profiles (high resolution temperature, } \\
\text { conductivity, velocity, pressure). }\end{array}$ \\
\hline
\end{tabular}

a See map, Fig. 2.

${ }^{\mathrm{b}}$ Operated and funded by the US National Oceanographic and Atmospheric Administration (NOAA), with additional support for shipborne sampling from the National Science Foundation.

overflew the flight path of the FAAM BAe146 with a similar airspeed $\left(\sim 100 \mathrm{~m} \mathrm{~s}^{-1}\right)$ and/or C-130 especially during the $20^{\circ} \mathrm{S}$ missions (see below).

\subsubsection{CIRPAS Twin Otter}

The Twin Otter operated by the Center for Interdisciplinary Remotely Piloted Aircraft Studies (CIRPAS) was instrumented to make turbulence, cloud microphysics, and aerosol measurements (Table 2) in the near coastal region of the VOCALS domain at $20^{\circ} \mathrm{S}, 72^{\circ} \mathrm{W}$ (a location termed here as Point Alpha, see Fig. 2). This relatively slow-moving aircraft $\left(\sim 60 \mathrm{~m} \mathrm{~s}^{-1}\right)$ made $5 \mathrm{~h}$ flights originating from Iquique Chile that allowed for $3 \mathrm{~h}$ of sampling at Point Alpha on 18 flights (Table 10).

\subsection{Ship platforms}

The two ships in VOCALS-REx sampled different locations at different times. The R/V Ronald H. Brown was operational for two phases, the first from 25 October to 2 November 2008 and the second from 10 November to 2 December 2008. The Peruvian R/V José Olaya operated from 2-
17 October 2008. Figure 3 provides a graphical representation of the ship sampling as a function of day and longitude. Figures describing the specific ship sampling strategies are disussed below. The ship measurements are designed to critically address several of the VOCALS hypotheses (Table 1), particularly those related to the upper ocean, aerosolcloud-drizzle interactions, the physical and chemical interactions between the upper ocean and the lower atmosphere, and those involving the sources and sinks of atmospheric aerosols.

\subsubsection{NOAA R/V Ronald H. Brown}

The R/V Ronald H. Brown is operated by the National Oceanographic and Atmospheric Administration (NOAA), and served as the primary shipborne sampling platform for measurements in the vicinity of $20^{\circ} \mathrm{S}$ from the coast out to $85^{\circ} \mathrm{W}$. The RHB also provided the means to deploy and recover moorings, drifters, and profiling floats during VOCALS REx. The RHB payload was designed to sample both the upper ocean and the lower atmosphere during REx, and details are given in Table 3. The multi-week RHB cruises 


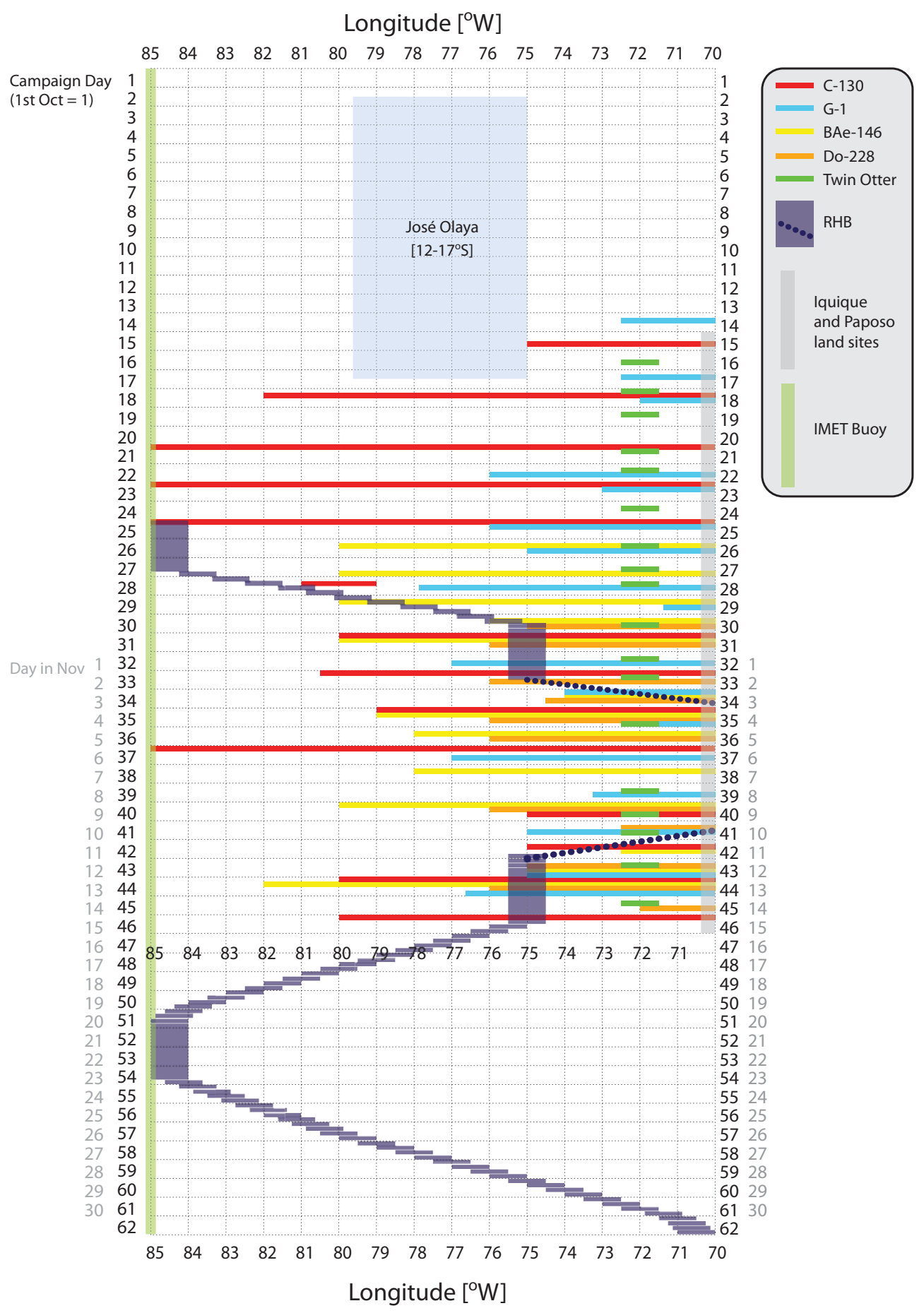

Fig. 3. Operations summary showing platform longitude against time during VOCALS-REx.

with 6 daily upper air soundings and continuous measurements by most sensors are able to capture details of the MBL diurnal variations and aerosol-cloud-drizzle evolution in a way that the aircraft platforms cannot. The paper by de Szoeke et al. (2010) documents meteorology, surface flux, and cloud remote sensing measurements from the RHB.

\subsubsection{Peruvian R/V José Olaya}

The José Olaya is surveyed by the Instituto del Mar del Perú (IMARPE) and operated in Peruvian near-coastal waters to provide extensive sampling of the upper ocean, with additional atmospheric measurements (Table 4). The sampling 
Table 4. Details of the R/V José Olaya Balandra measurements in VOCALS-REx.

\begin{tabular}{|c|c|}
\hline Location ${ }^{\mathrm{a}} /$ Dates & Measurements \\
\hline \multirow{6}{*}{$\begin{array}{l}\text { R/V José Olaya Balandra }{ }^{b} \\
\text { See map Fig. } 8 \\
\text { Oct } 2-17\end{array}$} & Atmospheric state: temperature, humidity, winds, cloud observations, photography. \\
\hline & $\begin{array}{l}\text { Upper air: regular radiosonde launches predominately within an area about } 200 \mathrm{~km} \text { off the Pisco-San Juan } \\
\text { region (see Fig. 8). }\end{array}$ \\
\hline & $\begin{array}{l}\text { Oceanography: } 113 \text { CTD profiles (temperature, conductivity, pressure) to } 1000 \mathrm{~m} \text { depth in the coastal } \\
\text { upwelling off southern Peru extending from the coast to } 80-320 \mathrm{~km} \text {, horizontal spacing from } 19 \mathrm{~km} \\
\text { (nearshore) to } 32-45 \mathrm{~km} \text { (offshore). The CTD was deployed with dissolved oxygen and fluorescence } \\
\text { sensors. Continuous records of VM-ADCP data (bin size } 8 \mathrm{~m} \text {, ping rate } 0.3 \mathrm{~s}-1 \text { ); underway sea surface } \\
\text { temperature/salinity; } 8 \text { surface drifters. Collection of water samples for determination of oxygen, nutrients } \\
\text { (phosphate, silicate, nitrate, nitrite), ph and chlorophyll- } a \text { concentrations in } 78 \text { stations. Underway } \\
\text { measurements of partial pressure of carbon dioxide }\left(p \mathrm{CO}_{2}\right) \text { complemented the biogeochemical } \\
\text { observations. }\end{array}$ \\
\hline & $\begin{array}{l}\text { Glider mission: continuous physical and biogeochemical data (temperature, salinity, dissolved oxygen, } \\
\text { fluorescence and turbidity) were collected by a repeating section between } 10 \mathrm{~km} \text { and } 100 \mathrm{~km} \text { from the } \\
\text { coast off Pisco. Observations every } 24 \mathrm{~s}, 5 \mathrm{~m} \text { along the vertical over the upper } 200 \mathrm{~m} \text { depth started in } \\
3 \text { October to } 14 \text { November } 2008 \text {. }\end{array}$ \\
\hline & $\begin{array}{l}\text { Biology: } 37 \text { Standard and } 35 \mathrm{WP}-2 \text { net sampling for phytoplankton and zooplankton qualitative analysis, } \\
\text { respectively; } 17 \text { Hensen net samples for zooplankton vertical distribution; } 153 \text { samples at depths } 0-75 \mathrm{~m} \\
\text { (Niskin bottles) for phytoplankton quantitative analysis); } 313 \text { samples collected underway at } 20 \mathrm{~min} \\
\text { interval with the Continuous Underway Fish Egg Sampler (CUFES). }\end{array}$ \\
\hline & $\begin{array}{l}\text { Fishery hydroacoustics: continuous records of echosounder EK60 at frequencies } 38,120 \text { and } 200 \mathrm{kHz} \text { to } \\
\text { document fish (in particular anchovy) abundance and patterns of distributions for the upper } 500 \mathrm{~m} \text { on the } \\
\text { vertical. Data averaged each } 1 \text { Basic Sample Unit }(1 \mathrm{~nm}) \text { horizontally. }\end{array}$ \\
\hline
\end{tabular}

a See map, Fig. 2 .

b Operated and funded by the Instituto del Mar del Perú (IMARPE), with additional support for upper air measurements and ship mobility from the National Science Foundation, Institut de Recherche pour le Développement and Institut National des Sciences de l'Univers for the glider mission.

strategy (see below) was designed to examine the coastal upwelling region off Pisco-San Juan and extended from the Peruvian coast to $100-300 \mathrm{~km}$ offshore. The upper and lower atmosphere, the upper ocean property distribution and circulation, the biogeochemical characteristics, the plankton community structure as well as fishery responses were measured in a comprehensive, multidisciplinary basis. Details on the instrumentation onboard the Olaya are provided in Table 4.

The National Center for Atmospheric Research (NCAR) Earth Observing Laboratory (EOL) deployed a GAUS (GPS Advanced Upper-air Sounding systems) radiosonde station on the José Olaya during VOCALS with sondes launched by IMARPE and IGP (Instituto Geofísico del Perú) and IRD (Institut pour le Récherche et Devéloppement) scientists. A total of 133 soundings were launched at varying intervals from 30 September to 17 October 2008. The launch sites were predominately within an area about $200 \mathrm{~km}$ off the coast of the Ica region of southern Peru. Vaisala RS92G radiosondes were used throughout.

\subsection{Fixed location sites}

\subsubsection{Paposo}

Extensive aerosol and meteorological measurements were made at two sites near Paposo $\left(25^{\circ} 01^{\prime} \mathrm{S}, 70^{\circ} 28^{\prime} \mathrm{W}\right)$ on the Northern Chilean coast (see map Figs. 2 and 4). In terms of the flow in the MBL, Paposo sits upwind of the primary focus area along the $20^{\circ} \mathrm{S}$ parallel and the measurements are designed to help constrain the physical and aerosol properties of airmasses leaving the continent to be advected over the broader SE Pacific region. Two sites were used near Paposo (Table 5) on the Northern Chilean coast. In-situ aerosol physical and chemical measurements, and meteorological sampling, were conducted at an elevated (upper) site $\left(25^{\circ} 00^{\prime} 22.55^{\prime \prime} \mathrm{S}, 70^{\circ} 27^{\prime} 02.01^{\prime \prime} \mathrm{W}, 690 \mathrm{~m}\right.$ a.s.l.) in the coastal range immediately adjacent to the ocean $(1.7 \mathrm{~km}$ east of the shore). Lidar profiles and soundings were made from a lower site near sea-level in the village of Paposo $\left(25^{\circ} 00^{\prime} 34.41^{\prime \prime} \mathrm{S}\right.$, $70^{\circ} 27^{\prime} 53.64^{\prime \prime} \mathrm{W}, 20 \mathrm{~m}$ a.s.l.) situated $100 \mathrm{~m}$ from the shore and $1.5 \mathrm{~km}$ to the WSW of the elevated site.

The elevated Paposo site is close to the peak of the hill in the coastal range in which it is situated (Fig. 4). 
Table 5. Details of the surface sites used in VOCALS-REx.

\begin{tabular}{|c|c|c|c|}
\hline Paposo (upper site) & $\begin{array}{l}25^{\circ} 00^{\prime} \mathrm{S} \\
70^{\circ} 27^{\prime} \mathrm{W} \\
690 \mathrm{~m} \\
\text { a.s.l. }\end{array}$ & $\begin{array}{l}\text { Oct } 15 \\
- \text { Nov } 15 \\
\text { (Jul } 23 \\
- \text { Nov } 15 \\
\text { for met. } \\
\text { and } \\
\text { radiation) }\end{array}$ & $\begin{array}{l}\text { Atmospheric state: temperature, humidity, winds, pressure (weather station), } \\
\text { downwelling shortwave and net (LW+SW) radiation (July 23-Nov 15). } \\
\text { Aerosols: aerosol size distribution ( } 20 \mathrm{~nm}-5 \mu \mathrm{m} \text {, SMPS/OPC); total CN (CPC, } \\
\text { Nov 4-15 only), aerosol composition (submicron impactors for ion and } \\
\text { gravimetric analysis); light scattering (Oct } 27-\mathrm{Nov} 15 \text {, Radiance Research } \\
\text { nephelometer, single wavelength); absorption (PSAP, Nov 4-15 only); black } \\
\text { carbon (aethelometer, Nov 4-15 only); Cloud droplet residuals (Nov 4-18 only, } \\
\text { Counterflow virtual impactor with instrumentation as at Paranal [see below] } \\
\text { behind, plus liquid water content); } \\
\text { Trace gases: } \mathrm{O}_{3} \text {. }\end{array}$ \\
\hline Paposo (lower site) & $\begin{array}{l}25^{\circ} 01^{\prime} \mathrm{S} \\
70^{\circ} 27^{\prime} \mathrm{W} \\
31 \quad \mathrm{~m} \\
\text { a.s.l. }\end{array}$ & $\begin{array}{l}\text { Oct } 15 \\
- \text { Nov } 15\end{array}$ & $\begin{array}{l}\text { Atmospheric state: temperature, humidity, winds, pressure (weather station), } \\
\text { downwelling shortwave and net }(\mathrm{LW}+\mathrm{SW} \text { ) radiation (July } 23-\mathrm{Nov} 15) \text {. Upper } \\
\text { air: multiple daily radiosonde launches }(2 \times \text { daily at } 00 / 12 \mathrm{UTC} \text {, Oct } 17-23 \text {; } \\
3 \times \text { daily at } 00 / 12 / 21 \mathrm{UTC} \text {, Oct } 24-\mathrm{Nov} 9 ; 4 \times \text { daily at } 00 / 06 / 18 / 21 \mathrm{UTC} \text {, Nov } \\
11-12 ; 5 \times \text { daily at } 00 / 06 / 12 / 18 / 21 \text {, Nov } 13-15) \text {, Vaisala RS80-15G sondes } \\
\text { Remote sensing: lidar backscatter from aerosols and clouds, polarized (mostly } \\
\text { vertical pointing, but some slant path scans, } 1.574 \mu \text { m wavelength, } 1.5 \mathrm{~m} \\
\text { maximum vertical resolution, linear and circular polarizations) }\end{array}$ \\
\hline Paranal & $\begin{array}{l}24^{\circ} 38^{\prime} \mathrm{S} \\
70^{\circ} 24^{\prime} \mathrm{W} \\
2635 \mathrm{~m} \\
\text { a.s.1. }\end{array}$ & $\begin{array}{l}\text { Oct } 17 \\
- \text { Nov } 4\end{array}$ & $\begin{array}{l}\text { Aerosols: Aerosol total concentration (TSI } 3010 \text { CPC, }>10 \mathrm{~nm} \text { ); Aerosol size } \\
\text { distributions (DMPS } 20-300 \mathrm{~nm} \text {, unheated/heated to } 50-400 \mathrm{C} \text {; OPC } \\
0.26-2.2 \mu \mathrm{m} \text { ); Volatility TDMA (not continuous, only occasionally range } \\
\text { 20-300 nm); Aerosol scattering (nephelometer) and light absorption (PSAP and } \\
\text { Aethelometer); Samples for single particle analysis. }\end{array}$ \\
\hline Iquique & $\begin{array}{l}20^{\circ} 16^{\prime} \mathrm{S} \\
70^{\circ} 08^{\prime} \mathrm{W} \\
15 \mathrm{~m} \text { a.s.l. }\end{array}$ & $\begin{array}{l}\text { Oct } 15 \\
- \text { Nov } 15\end{array}$ & Upper air: $6 \times$ daily radiosonde launches $(00,04,08, \ldots$ UTC $)$ \\
\hline IMET Buoy & $\begin{array}{l}19^{\circ} 43^{\prime} \mathrm{S}, \\
85^{\circ} 35^{\prime} \mathrm{W}\end{array}$ & $\begin{array}{l}\text { Entire } \\
\text { period }^{\mathrm{a}}\end{array}$ & $\begin{array}{l}\text { Atmospheric state: Winds (propeller/vane), temperature, pressure, humidity } \\
\text { (capacitance), precipitation (tipping bucket); } \\
\text { Radiation: downwelling longwave and shortwave irradiance. } \\
\text { Oceanography: upper ocean temperature, salinity and currents, with depth } \\
\text { sampling varying over time. }\end{array}$ \\
\hline DART/SHOA Buoy & $\begin{array}{l}19^{\circ} 34^{\prime} \mathrm{S}, \\
73^{\circ} 47^{\prime} \mathrm{W}\end{array}$ & $\begin{array}{l}\text { Oct } 31 \\
- \text { end }^{\mathrm{b}}\end{array}$ & $\begin{array}{l}\text { Atmospheric state: winds (propeller/vane), temperature, pressure (from } 31 \text { Oct } \\
2008 \text { only), humidity (capacitance, from } 31 \text { Oct } 2008 \text { only); } \\
\text { Radiation: downwelling longwave and shortwave irradiance. } \\
\text { Oceanography: temperature and salinity at } \mathbf{1 4} \text { depths from } \mathbf{1 0 - 3 1 0 ~} \mathbf{~ m}\end{array}$ \\
\hline
\end{tabular}

\footnotetext{
a The IMET buoy has been providing data nearly continuously since October 2000. Data are available from the VOCALS data archive. A detailed description of the meteorological instruments and their performance can be found in Colbo and Weller (2009). Oceanographic measurements are detailed at http://uop.whoi.edu.

b The DART/SHOA buoy was operational 31 October 2008-3 Jan 2010. Data are available from the VOCALS data archive.
}

Meteorological measurements from an automatic weather station at the upper Paposo site were started on 24 July 2008 and continued through the end of November 2008. During the period of intensive REx sampling at Paposo (17 October15 November 2008), the upper site was almost continually within the marine boundary layer (MBL), although earlier in the season the inversion was occasionally lower which allowed sampling above the MBL. Table 5 details the measurements made at the upper Paposo site. Aerosol sampling was carried out using a custom-made multidirectional aerosol inlet and a multiport sampling configuration (see Fig. 4), with additional sampling lines for aerosols during 4-15 November. The primary sampling line was used to connect with the scanning mobility particle spectrometer (SMPS), optical particle counter (OPC), nephelometers, aethalometer and ozone analyzer, and the same line was used to sample submicron
$(<1 \mu \mathrm{m}$ diameter) aerosols on filters for chemical analysis. Aerosol filter measurements are described further in Chand et al. (2010). Meteorological and radiation measurements at the upper site were made by the University of Chile, and these measurements are described further in (Muñoz et al., 2011).

At the lower Paposo site, an eye-safe $1.574 \mu \mathrm{m}$ lidar, a weather station, and a sounding system were installed at the Paposo foothill site near the coast (Table 5 and map Fig. 4). The lidar was primarily vertically-pointing but some slant path scans were also performed. An identical set of meteorological parameters to that measured at the upper site was measured at the lower site. Multiple soundings per day were made from the site (Table 5 provides details of the launch times). 
Table 6. Details of C-130 aircraft missions conducted in the VOCALS Regional Experiment.

\begin{tabular}{|c|c|c|c|c|c|}
\hline \multirow[t]{2}{*}{ Flight } & \multirow[t]{2}{*}{ Date } & \multicolumn{2}{|c|}{ Times [UTC] } & \multirow[t]{2}{*}{ Mission/Location } & \multirow[t]{2}{*}{ Notes } \\
\hline & & $\mathrm{T} / \mathrm{O}$ & Land & & \\
\hline RF01 & Oct 15 & $16: 49$ & $20: 11$ & Partial $20^{\circ} \mathrm{S}$ to $20^{\circ} \mathrm{S}, 75^{\circ} \mathrm{W}$ & Day mission, solid cloud deck \\
\hline RF02 & Oct 18 & 13:04 & $21: 27$ & $20^{\circ} \mathrm{S} / \mathrm{POC}$ Drift & $\begin{array}{l}\text { Day mission, solid cloud deck, polluted with little drizzle. } \\
\text { POC sampling of rift-like feature }\end{array}$ \\
\hline RF03 & Oct 21 & 06:02 & $14: 22$ & $20^{\circ} \mathrm{S}$ & $\begin{array}{l}\text { Night mission, solid cloud deck, significant microphysical } \\
\text { gradient; notably shallow MBL }\end{array}$ \\
\hline RF04 & Oct 23 & 06:01 & $14: 20$ & $20^{\circ} \mathrm{S}$ & Night mission, broken/open cells at far west \\
\hline RF05 & Oct 25 & $06: 32$ & $15: 25$ & $20^{\circ} \mathrm{S}$ & Overflight of RHB \\
\hline RF06 & Oct 28 & $06: 20$ & $15: 10$ & POC Drift & Night mission, very clear POC edge sampled \\
\hline RF07 & Oct 31 & 06:03 & $14: 58$ & POC Drift $/ 20^{\circ} \mathrm{S}$ & Night mission, \\
\hline RF08 & Nov 2 & 06:00 & $15: 20$ & POC Drift & Night mission, overflight of RHB \\
\hline RF09 & Nov 4 & 06:02 & $14: 54$ & POC Drift $/ 20^{\circ} \mathrm{S}$ & Night mission, POC sampling \\
\hline RF10 & Nov 6 & $06: 10$ & $14: 19$ & $20^{\circ} \mathrm{S}$ & Night mission, overcast with breaks and drizzling large \\
\hline RF11 & Nov 9 & $12: 59$ & $21: 34$ & Pollution Survey to $30^{\circ} \mathrm{S}$ & $\begin{array}{l}\text { mesoscale cells at west } \\
\text { Day mission, Variable cloud morphology along coast, } \\
\text { pollution plumes }\end{array}$ \\
\hline RF12 & Nov 11 & $12: 56$ & $21: 44$ & Pollution Survey to $30^{\circ} \mathrm{S}$ & Day mission, Overcast cloud, overflight of RHB \\
\hline RF13 & Nov 13 & 13:00 & $21: 55$ & $\mathrm{POC} / 20^{\circ} \mathrm{S}$ & $\begin{array}{l}\text { Day mission, Extensive clearing near coast, then thick cloud } \\
\text { with POC }\end{array}$ \\
\hline RF14 & Nov 15 & $13: 00$ & $22: 00$ & POC Drift & $\begin{array}{l}\text { Day mission, rift/clearing sampled, high } \mathrm{SO}_{2} \text { just above } \mathrm{MBL} \\
\text { at } 80^{\circ} \mathrm{W}\end{array}$ \\
\hline
\end{tabular}

\subsubsection{Paranal}

A suite of aerosol measurements (see Table 5) in the freetroposphere were also made for just under three weeks (17 October to 4 November) at the high altitude European Southern Observatory at Paranal $\left(24^{\circ} 37^{\prime} 39.00^{\prime \prime} \mathrm{S}\right.$, $70^{\circ} 24^{\prime} 17.85^{\prime \prime} \mathrm{W}, 2625 \mathrm{~m}$ a.s.1.), see map Fig. 4.

\subsubsection{Iquique}

The National Center for Atmospheric Research (NCAR) Earth Observing Laboratory (EOL) deployed a GAUS (GPS Advanced Upper-air Sounding systems) radiosonde station located in Iquique at the Universidad Arturo Prat Marine Sciences Campus $\left(20^{\circ} 16^{\prime} 15^{\prime \prime} \mathrm{S}, 70^{\circ} 07^{\prime} 52^{\prime \prime} \mathrm{W}, 15 \mathrm{~m}\right.$ a.s.1.). The stations was operated with the assistance of staff and students (see map Fig. 4). The launch site was on a steep slope, approximately $100 \mathrm{~m}$ inland and $20 \mathrm{~m}$ above the shoreline. A total of 192 radiosondes were launched at 4 hourly intervals from 15 October to 15 November 2008. Weather conditions at the site were generally clear and calm, with light sea (daytime) and land (nighttime) breezes. Vaisala RS92G radiosondes were used throughout.

\subsection{IMET Buoy}

The Improved Meteorology (IMET) moored buoy is situated at approximately $20^{\circ} \mathrm{S}, 85^{\circ} \mathrm{W}$ (see Table 5 for precise location) at the western end of the sampling conducted during VOCALS-REx. The mooring has been operational since October 2000 and has provided an excellent intermediate- term record of both the surface meteorology/radiation, and the upper ocean thermodynamic and dynamic structure. The meteorological and radiation measurements (Table 5) on the IMET buoy are described and their performance evaluated in Colbo and Weller (2009). The upper ocean measurements include temperature profiles, sea-surface temperature, salinity and currents. Further details can be found on the WHOI Upper Ocean Processes website (Table 5).

\subsection{DART/SHOA Buoy}

The Deep-ocean Assessment and Reporting of Tsunamis/Servicio Hidrográfico y Oceanográfico de la Armada de Chile (DART/SHOA) moored buoy at approximately $19.5^{\circ} \mathrm{S}, 74^{\circ} \mathrm{W}$ (see Table 5 for precise location) has been instrumented with meteorological and oceanographic measurements from October 2006 through January 2010. Meteorological measurements similar to those on the IMET buoy (Colbo and Weller, 2009) were made during much of this period. Upper ocean measurements of temperature and salinity at 14 depths were also made from 2006 onwards.

\section{Sampling strategies}

\subsection{Matching sampling strategy to the VOCALS hypotheses}

The REx sampling strategy was carefully designed and coordinated between platforms to test key VOCALS hypotheses listed in Table 1. Approximately half way through the field 
Table 7. Details of BAe-146 aircraft missions conducted in the VOCALS Regional Experiment.

\begin{tabular}{|c|c|c|c|c|c|}
\hline \multirow[t]{2}{*}{ Flight } & \multirow[t]{2}{*}{ Date } & \multicolumn{2}{|c|}{ Times [UTC] } & \multirow[t]{2}{*}{ Mission/Location } & \multirow[t]{2}{*}{ Notes } \\
\hline & & $\mathrm{T} / \mathrm{O}$ & Land & & \\
\hline B408 & Oct 26 & $10: 05$ & $21: 27$ & $20^{\circ} \mathrm{S} \mathrm{XS}$ & $\begin{array}{l}\text { Profiling up to } 1500 \mathrm{~m} \text { out to } 79.5^{\circ} \mathrm{W} \text { with saw-tooth profile to } 4800 \mathrm{~m} \\
\text { at west-most point. Reciprocal return. Increasing cloud base and tops } \\
\text { with distance offshore }\end{array}$ \\
\hline B409 & Oct 27 & $19: 59$ & $00: 29$ & POC Drift & $\begin{array}{l}\text { Sampled open cellular (POC) region at } \sim 78^{\circ} \mathrm{W} \text { at dusk. Very low } \mathrm{CN} \\
\text { in POC.C-130 sampled same advected airmass } 12 \mathrm{~h} \text { later }\end{array}$ \\
\hline B410 & Oct 29 & 09:59 & $15: 16$ & $20^{\circ} \mathrm{S} \mathrm{XS}$ & $\begin{array}{l}\text { Detour to rendezvous with DART buoy on outbound leg only. Profiling } \\
\text { to } 1600 \mathrm{~m} \text { with deep profile to } 4600 \mathrm{~m} \text { at west-most point. }\end{array}$ \\
\hline B411 & Oct 30 & $10: 25$ & $15: 48$ & RHB cosampling & $\begin{array}{l}\text { RHB on station near the DART Buoy. Cloud and MBL profiles en } \\
\text { route. Several 20-min back and forth legs (parallel to mean wind) over }\end{array}$ \\
\hline B412 & Oct 31 & 09:47 & $14: 52$ & $20^{\circ} \mathrm{S} \mathrm{XS}$ & $\begin{array}{l}\text { RHB } \\
\text { Profiling up to } 1500 \mathrm{~m} \text { out to } 79.5^{\circ} \mathrm{W} \text {. High level return with } \\
7 \text { dropsondes, every degree from } 78^{\circ} \mathrm{W} \text { to } 72^{\circ} \mathrm{W} \text {. }\end{array}$ \\
\hline B413 & Nov 3 & $11: 03$ & $16: 05$ & Ilo pollution survey & $\begin{array}{l}\text { Profiling from Arica to DART buoy to study coastal gradient in } \\
\text { pollution, followed by coastal fly-by aligned to mean wind direction to } \\
\text { study potential pollution from the Ilo smelter. No evidence of fresh } \\
\text { pollution due to smelter down-time. } 4 \text { dropsondes }\end{array}$ \\
\hline B414 & Nov 4 & 09:44 & $15: 04$ & $20^{\circ} \mathrm{S} \mathrm{XS}$ & $\begin{array}{l}\text { Profiling up to } 1500 \mathrm{~m} \text { out to } 79.5^{\circ} \mathrm{W} \text {. High level return with } \\
7 \text { dropsondes, every degree from } 78^{\circ} \mathrm{W} \text { to } 72^{\circ} \mathrm{W}\end{array}$ \\
\hline B415 & Nov 5 & 09:12 & $14: 33$ & POC Drift & $\begin{array}{l}\text { Sampled open cellular (POC) region at } \sim 78^{\circ} \mathrm{W} \text {. Very low } \mathrm{CN} \\
\text { observed in POC. High-level return to base with } 10 \text { dropsondes } \\
\text { released. }\end{array}$ \\
\hline B416 & Nov 7 & $10: 32$ & $15: 27$ & POC Drift & $\begin{array}{l}\text { Sampled open cellular }(\mathrm{POC}) \text { region at } \sim 78^{\circ} \mathrm{W} \text {. Very low } \mathrm{CN} \\
\text { observed in POC. High-level return to base with } 11 \text { dropsondes } \\
\text { released ( } 2 \text { into POC) }\end{array}$ \\
\hline B417 & Nov 9 & 09:58 & $21: 34$ & $20^{\circ} \mathrm{S} \mathrm{XS}$ & $\begin{array}{l}\text { Profiling to } 1600 \mathrm{~m} \text { with deep profile to } 3200 \mathrm{~m} \text { at west-most point. } \\
\text { Reciprocal return. Transition in wind dynamics (coastal jet) observed } \\
\text { at } 75^{\circ} \mathrm{W} \text {. }\end{array}$ \\
\hline B418a & Nov 11 & $11: 31$ & $16: 13$ & $\begin{array}{l}\text { Coastal pollution } \\
\text { Survey south from } \\
\text { Arica }\end{array}$ & $\begin{array}{l}\text { Fly-by along coast ( } 100 \mathrm{~km} \text { offshore) in straight line from Arica to } \\
\text { Antofagasta, with MBL and cloud saw-tooth profiling. Refuel at } \\
\text { Antofagasta. }\end{array}$ \\
\hline B $418 b$ & Nov 11 & $17: 49$ & $21: 17$ & & $\begin{array}{l}\text { Return to Arica with legs directed offshore and parallel to mean wind } \\
\text { to study land source Lagrangians. Several point sources noted. }\end{array}$ \\
\hline B419 & Nov 12 & $11: 29$ & $16: 51$ & RHB Cosampling & $\begin{array}{l}\text { Straight run from Arica to Ron Brown whilst on station near the DART } \\
\text { Buoy performing cloud and MBL profiles en route. Several 20-min } \\
\text { reciprocal legs (parallel to mean wind) performed, centred on Ron }\end{array}$ \\
\hline B420 & Nov 13 & 09:58 & $15: 13$ & $20^{\circ} \mathrm{S} \mathrm{XS} / \mathrm{POC}$ & $\begin{array}{l}\text { Brown, with cloud, MBL and deep profiles to } 3.2 \mathrm{~km} \\
\text { profiling up to } 1500 \mathrm{~m} \text { out to } 81^{\circ} \mathrm{W} \text { with a high level return and } 10 \\
\text { sonde drops at } 1^{\circ} \text { intervals. POC sampled briefly at western point with } \\
2 \text { sondes dropped into cloud-clearing on return. }\end{array}$ \\
\hline
\end{tabular}

phase, when the RHB was in between its two cruise legs, an "all-hands" meeting was held in Arica to discuss progress and strategize about the needs for sampling during the remainder of the campaign. Some important adjustments to the sampling strategy were made at this point.

Briefly, the VOCALS aerosol-cloud-drizzle hypotheses can be paraphrased as

- Hla: aerosol variations significantly affect drizzle formation.

- $H 1 b / d$ : drizzle-induced aerosol scavenging is required for POC formation and maintenance.

- HIc: cloud droplet radii are smaller near the coast due to anthropogenic aerosol emissions from South America.
In the REx region, both repeated surveying and sampling of specific features are useful for testing these hypotheses. Repeated sampling of the persistent gradients in aerosols, clouds and precipitation between nearshore and offshore regimes allows robust features of the gradient region to stand out and can be used to study correlations among aerosols, cloud macrostructure, and meteorology present on individual days. POCs present extreme examples (typically POCs are among the very cleanest and most strongly drizzling of airmasses in the SEP) that challenge our physical understanding of cloud-aerosol-precipitation interaction. Thus, an aircraft sampling strategy mainly focused on repeated sampling across the aerosol gradient region (with a few missions at the end parallel to the coast to characterize the offshore aerosol distribution upwind of the main VOCALS-REx study region), interspersed by opportunistic sampling of any POCs 

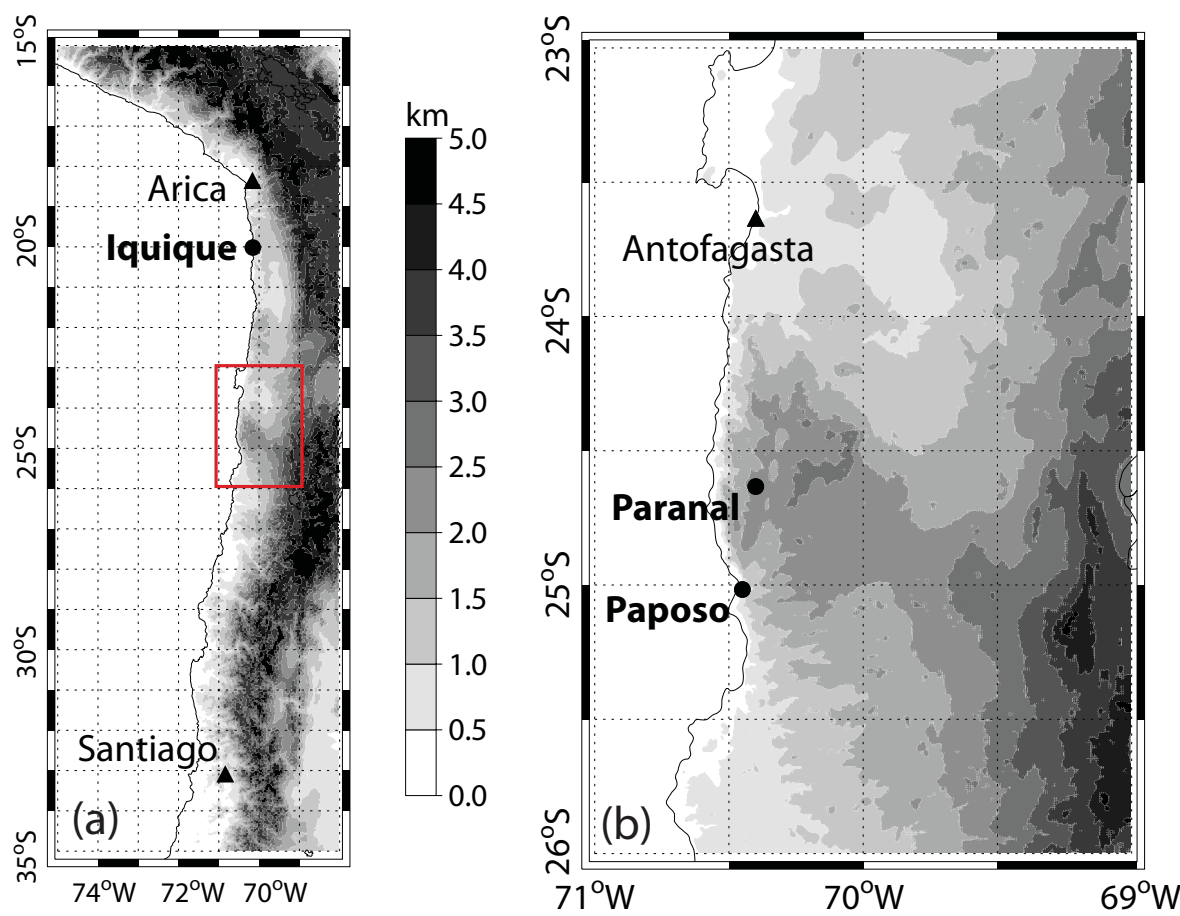

\section{Paposo sites}

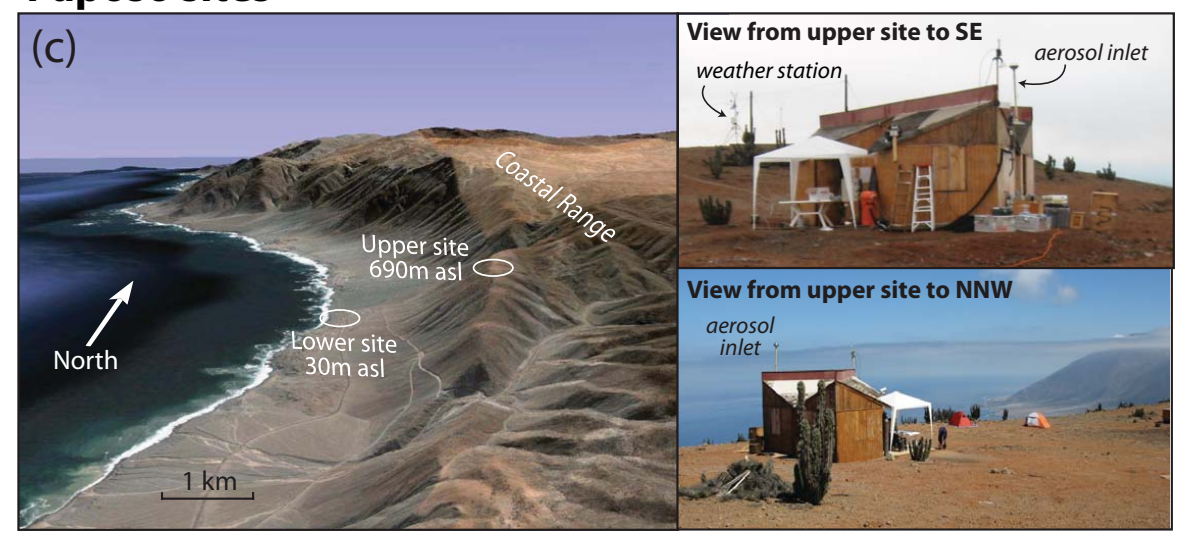

Fig. 4. (a) Map showing location of ground sites used in VOCALS-REx, with (b) a zoomed in map for the red boxed area in (a). Panel (c) shows a Google Earth terrain image showing the Paposo sites looking approximately northward, together with photographs from the upper (elevated) Paposo site.

within range. Because of the desire for repeated sampling strategies, the aircraft favored particular times of day and did not attempt to characterize the diurnal variability of the cloud-topped boundary layer. The ship, mooring, and landbased sampling was aimed at complementing the aircraft through a better characterization of diurnal variability along $20^{\circ} \mathrm{S}$ (particularly with the RHB and the Iquique sounding site) and of the upstream anthropogenic aerosol sources (the Paposo and Paranal land sites).

The observational VOCALS coupled ocean-atmosphere hypotheses in Table 1 can be summarized:
- $H 2 b / d$ : the offshore ocean mixed layer SST and salinity are decreased by ocean mesoscale eddy transports and entrainment from below. Oceanic DMS affects the boundary layer aerosol both in the upwelling zone and far offshore.

- $H 2 c$ : a subsidence wave driven by slope heating on the Andes measurably affects the diurnal cycle of stratocumulus.

VOCALS-REx tackled these hypotheses mainly with a shipbased strategy (RHB and José Olaya), through sampling of clouds and atmospheric profiles through the diurnal cycle for $\mathrm{H} 2 \mathrm{c}$ and survey-style sampling for $\mathrm{H} 2 \mathrm{~b} / \mathrm{d}$. 

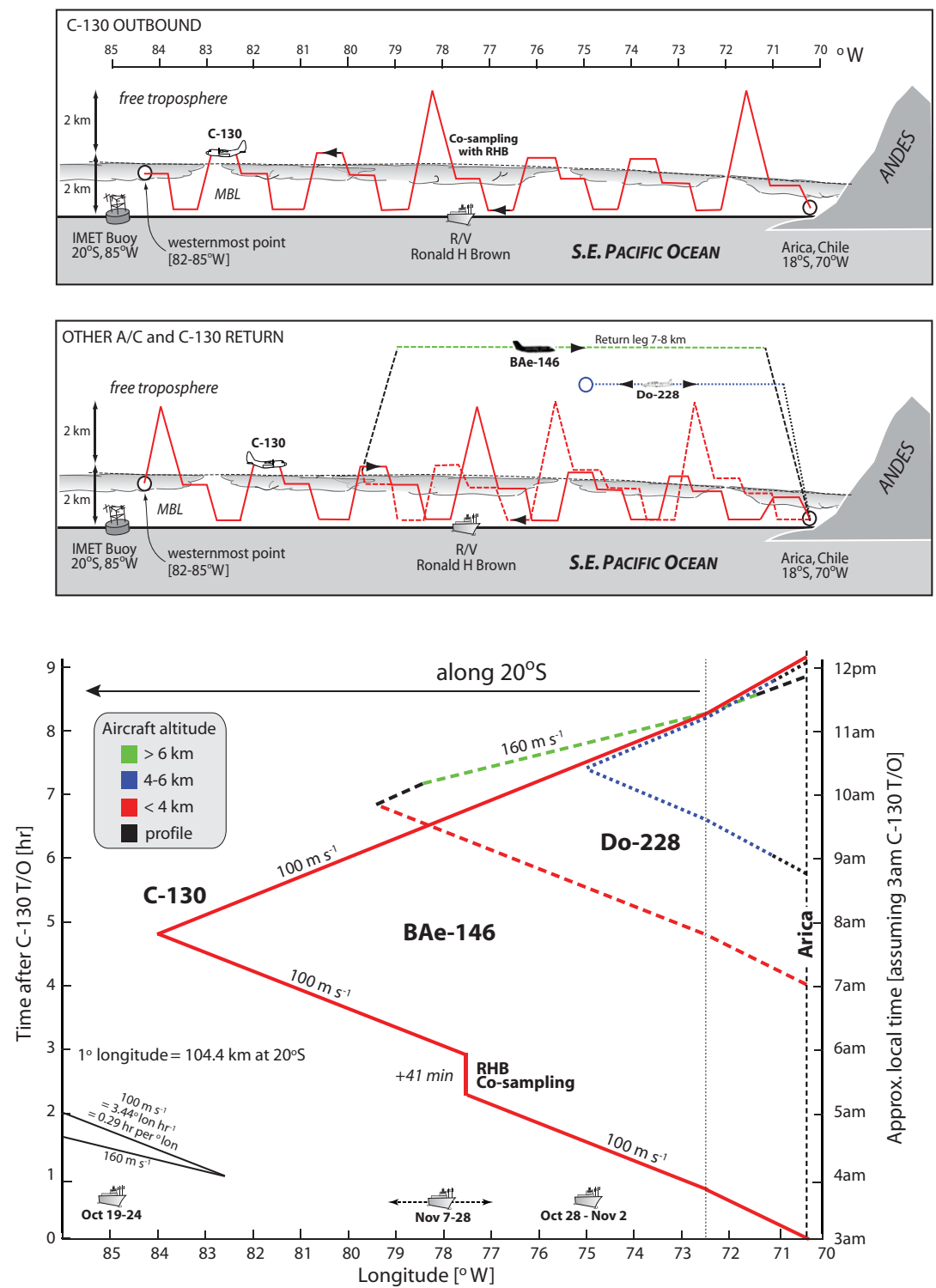

Fig. 5. Cross Section mission flight plan. Up to three aircraft (BAe-146, C-130, Do 228) were used in this mission, but in a number of cases only a single aircraft was used. In all cases, the aircraft flew from Arica to $20^{\circ} \mathrm{S}, 72^{\circ} \mathrm{W}$ and then flew westward along the $20^{\circ} \mathrm{S}$ parallel. The schematic shown here is for all three aircraft - the upper two panels show longitude-height diagrams while the lower panel shows a timelongitude plot color coded with altitude range. The C-130 flew $60 \mathrm{~km}$ (10 min) straight and level legs near the surface ( $150 \mathrm{~m}$ altitude), in the cloud (typically $800-1300 \mathrm{~m}$ altitude) and above cloud (300 $\mathrm{m}$ above cloud top), interspersed with profiles up to $3000-4000 \mathrm{~m}$. The C-130 typically reached $85^{\circ} \mathrm{W}$. The BAe- 146 flew similar outbound legs, out to $79-80^{\circ} \mathrm{W}$ but then flew the return leg at high altitude releasing dropsondes and making radiation measurements when working in concert with the $\mathrm{C}-130$. When operating alone the BAe-146 repeated the in-situ sampling on the return leg. The Do-228, when employed in this mission, flew legs at approximately $4000 \mathrm{~m}$ altitude using the nadir-viewing lidar and hyperspectral imagers to characterize clouds and aerosols below. There was a concerted effort for the three aircraft to sample the same location as closely in time as possible on the return leg (see bottom panel).

For both sets of hypotheses, IMET/DART mooring observations, satellite observations, and modeling on a range of scales are envisioned as vital complements to the in-situ observations.

\subsection{Aircraft missions}

The following aircraft mission strategies were used during VOCALS-REx: 


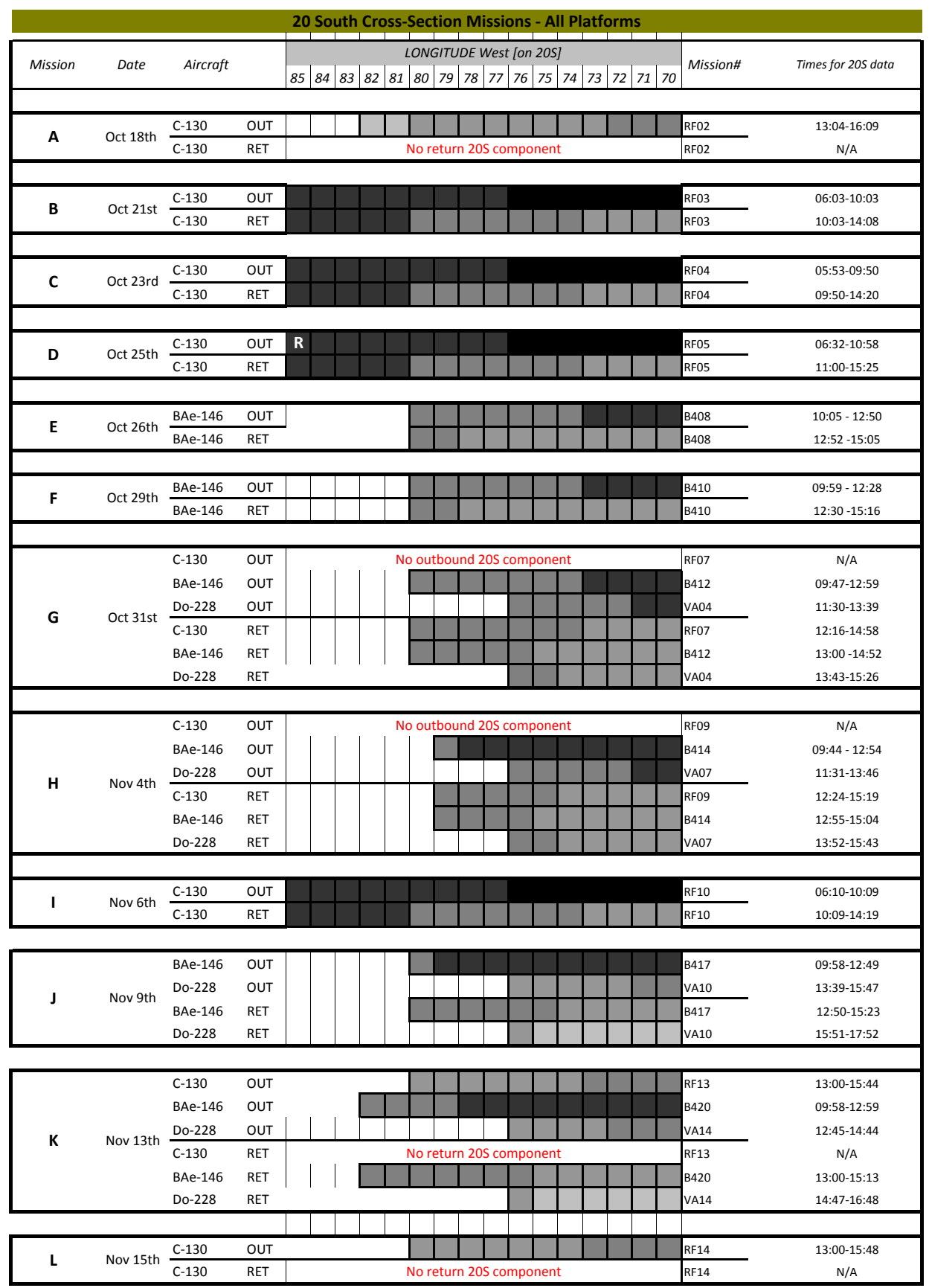

$\left.\begin{array}{|lll|}\hline \text { Time Key } & \begin{array}{c}\text { Time } \\ \text { [local] }\end{array} & \multicolumn{1}{c|}{\text { Time }} \\ \text { [UTC] }\end{array}\right]$

Fig. 6. Cross Section missions summary as a function of date and longitude along $20^{\circ} \mathrm{S}$. Color coding shows the approximate local/UTC time of sampling. Times for which Cross-Section mission data is available are provided at right. Individual aircraft flight numbers are also given. Missions with missing outbound or return legs indicate that the aircraft was involved in a different mission for part of its flight.

1. Cross-Section (XS) missions along $20^{\circ} \mathrm{S}$ latitude (or other proximal latitudes) from the coast to close to the IMET buoy at $85^{\circ} \mathrm{W}$ (mission plan shown in Fig. 5) aimed to sample longitudinal gradients in clouds, the MBL, and aerosols. A total of 12 Cross-Section missions were flown along $20^{\circ} \mathrm{S}$ during REx (mission details shown in Fig. 6), with more flown along nearby latitudes (especially by the G-1 aircraft, see Table 8). Emphasis in these missions was on good sampling within the MBL and the air in the lowermost part of the free troposphere that would be entrained into the MBL, but profile measurements were also made up to $3-4 \mathrm{~km}$ to capture aerosol layers and the vertical thermodynamic structure aloft. The BAe-146 missions also 
Table 8. Details of G-1 aircraft missions conducted in the VOCALS Regional Experiment.

\begin{tabular}{|c|c|c|c|c|c|}
\hline \multirow[t]{2}{*}{ Flight } & \multirow[t]{2}{*}{ Date } & \multicolumn{2}{|c|}{ Times [UTC] } & \multirow[t]{2}{*}{ Mission/Location } & \multirow[t]{2}{*}{ Notes } \\
\hline & & $\mathrm{T} / \mathrm{O}$ & Land & & \\
\hline 081014a & $\begin{array}{l}\text { Oct } \\
14\end{array}$ & $15: 54$ & $18: 26$ & $19^{\circ} \mathrm{S} \mathrm{XS}$ & $\begin{array}{l}\text { Solid clouds, repeated transects at different altitudes, below, in } \\
\text { and above clouds }\end{array}$ \\
\hline 081017a & $\begin{array}{l}\text { Oct } \\
17\end{array}$ & 13:00 & $16: 50$ & $19^{\circ} \mathrm{S} \mathrm{XS}$ & $\begin{array}{l}\text { Solid clouds, repeated transects between } 73^{\circ} \text { and } 74^{\circ} \mathrm{W} \text {, } \\
\text { vertical profile }\end{array}$ \\
\hline 081018a & $\begin{array}{l}\text { Oct } \\
18\end{array}$ & 13:07 & $15: 16$ & $19^{\circ} \mathrm{S} \mathrm{XS}$ & Solid clouds, flight aborted \\
\hline 081022a & $\begin{array}{l}\text { Oct } \\
22\end{array}$ & $16: 32$ & $19: 57$ & $19^{\circ} \mathrm{S} \mathrm{XS}$ & $\begin{array}{l}\text { Solid clouds, repeated transects at different altitudes, below, in } \\
\text { and above clouds, strong longitudinal gradient cloud and } \\
\text { aerosol properties }\end{array}$ \\
\hline 081023a & $\begin{array}{l}\text { Oct } \\
23\end{array}$ & $12: 49$ & $16: 35$ & SW to Point Alpha & $\begin{array}{l}\text { Broken clouds, } \mathrm{C} 130 \text { intercomparison, repeated transects at } \\
\text { different altitudes, below, in and above clouds }\end{array}$ \\
\hline 081025a & $\begin{array}{l}\text { Oct } \\
25\end{array}$ & 13:03 & 17:07 & SW to Point Alpha & $\begin{array}{l}\text { Broken clouds, repeated transects at different altitudes, below, } \\
\text { in and above clouds, strong longitudinal gradient cloud and } \\
\text { aerosol properties }\end{array}$ \\
\hline $081026 a$ & $\begin{array}{l}\text { Oct } \\
26\end{array}$ & 13:01 & $16: 36$ & $\begin{array}{l}\text { SW to Point Alpha, then } \\
20^{\circ} \mathrm{XS}\end{array}$ & $\begin{array}{l}\text { Broken clouds, Twin Otter intercomparison, repeated transects } \\
\text { at different altitudes, below, in and above clouds, longitudinal } \\
\text { gradient cloud properties }\end{array}$ \\
\hline 081028a & $\begin{array}{l}\text { Oct } \\
28\end{array}$ & $12: 58$ & $17: 16$ & $18.5^{\circ} \mathrm{S} \mathrm{XS}$ & $\begin{array}{l}\text { Clouds thicker to west, single transect below, in and above } \\
\text { clouds, strong longitudinal gradient in physical, cloud and } \\
\text { aerosol properties }\end{array}$ \\
\hline 081029a & $\begin{array}{l}\text { Oct } \\
29\end{array}$ & $15: 58$ & $19: 33$ & $\begin{array}{l}\text { Coastal pollution survey to } \\
23^{\circ} \mathrm{S}\end{array}$ & $\begin{array}{l}\text { Broken clouds, constant altitude to south, below, in and above } \\
\text { clouds on return }\end{array}$ \\
\hline 081101a & Nov 1 & $12: 57$ & $16: 57$ & $18.5^{\circ} \mathrm{S} \mathrm{XS}$ & $\begin{array}{l}\text { Variable cloud structures, below, in and above clouds to west, } \\
\text { constant altitude on return, strong longitudinal gradient in } \\
\text { physical, cloud and aerosol properties }\end{array}$ \\
\hline 081103a & Nov 3 & $12: 58$ & $16: 51$ & $18.5^{\circ} \mathrm{S}$ XS & $\begin{array}{l}\text { Clear-air near coast and at } 72^{\circ} \mathrm{W} \text {, repeated transects below, in, } \\
\text { and above clouds }\end{array}$ \\
\hline 081104a & Nov 4 & $11: 57$ & $16: 02$ & $\mathrm{SW}$ to $19.5^{\circ} \mathrm{S}, 72^{\circ} \mathrm{W}$ & $\begin{array}{l}\text { Clear air near coast and at } 72^{\circ} \mathrm{W}, \mathrm{C}-130 \text { intercomparison, } \\
\text { repeated transects below, in and above clouds }\end{array}$ \\
\hline 081106a & Nov 6 & $11: 57$ & $16: 21$ & $18.5^{\circ} \mathrm{S} \mathrm{XS}$ & $\begin{array}{l}\text { Solid clouds, below, in and above clouds to west, constant } \\
\text { altitude on return, strong longitudinal gradient in cloud and } \\
\text { aerosol properties }\end{array}$ \\
\hline $081108 \mathrm{a}$ & Nov 8 & $12: 55$ & $16: 31$ & $18.5^{\circ} \mathrm{S} \mathrm{XS}$ & $\begin{array}{l}\text { Broken clouds, longitudinal gradient in cloud and aerosol } \\
\text { properties }\end{array}$ \\
\hline 081110a & $\begin{array}{l}\text { Nov } \\
10\end{array}$ & 13:02 & $16: 50$ & $\mathrm{SW}$ to $20^{\circ} \mathrm{S}, 75^{\circ} \mathrm{W}$ & $\begin{array}{l}\text { Clear near coast, variable clouds to SW, below, in and above } \\
\text { clouds, short transects at SW terminus, strong longitudinal } \\
\text { gradient in cloud and aerosol properties }\end{array}$ \\
\hline 081112a & $\begin{array}{l}\text { Nov } \\
12\end{array}$ & $13: 20$ & $16: 55$ & $18.5^{\circ} \mathrm{S} \mathrm{XS}$ & $\begin{array}{l}\text { Broken clouds at } 73.5^{\circ} \mathrm{W} \text {, solid elsewhere, below, in and above } \\
\text { clouds, short transects at } \mathrm{W} \text { terminus, longitudinal gradient in } \\
\text { cloud and aerosol properties }\end{array}$ \\
\hline 081113a & $\begin{array}{l}\text { Nov } \\
13\end{array}$ & $12: 54$ & $16: 41$ & $18.5^{\circ} \mathrm{S} \mathrm{XS}$ & $\begin{array}{l}\text { Mostly clear, below, in and above clouds to west, constant } \\
\text { altitude on return, longitudinal gradient cloud and aerosol } \\
\text { properties }\end{array}$ \\
\hline
\end{tabular}

included a return leg at an altitude of 5-7 km from which dropsondes were launched and nadir radiometers were operated. Three XS missions were conducted in which three aircraft (C-130, BAe-146 and Do-228) all conducted near-simultaneous cosampling, with the C130 sampling in the MBL, and the Do- 228 and BAe146 flying in the free troposphere and serving as remotesensing/dropsonde platforms;
2. POC-drift missions which target either existing pockets of open cells (POCs) within overcast stratocumulus, or areas prone to POC development, and track these as they advect with the flow. Focus in these missions was on characterizing the marine boundary layer and the lowermost part of the free troposphere. A typical flight plan is shown in Fig. 7, and a summary of the POC sampling from the various platforms is given in Table 11. Some sawtooth runs provided additional vertical information without compromising too severely the number of straight and level flight legs. On one occasion (27/28 

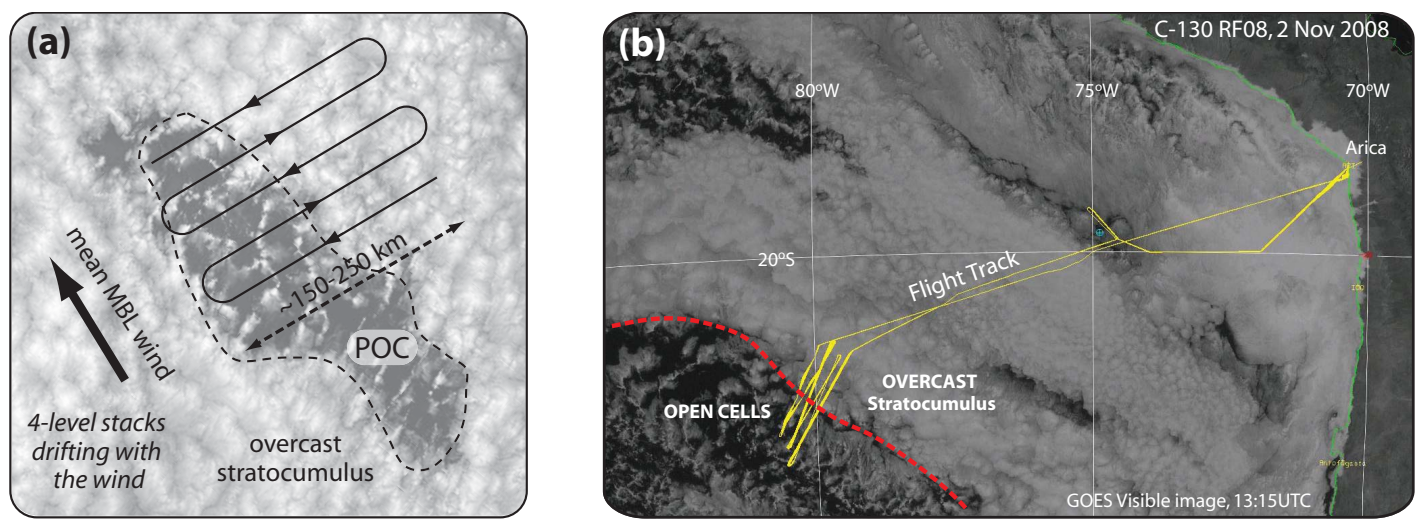

(c) OPEN CELL REGION

OVERCAST STRATOCUMULUS REGION

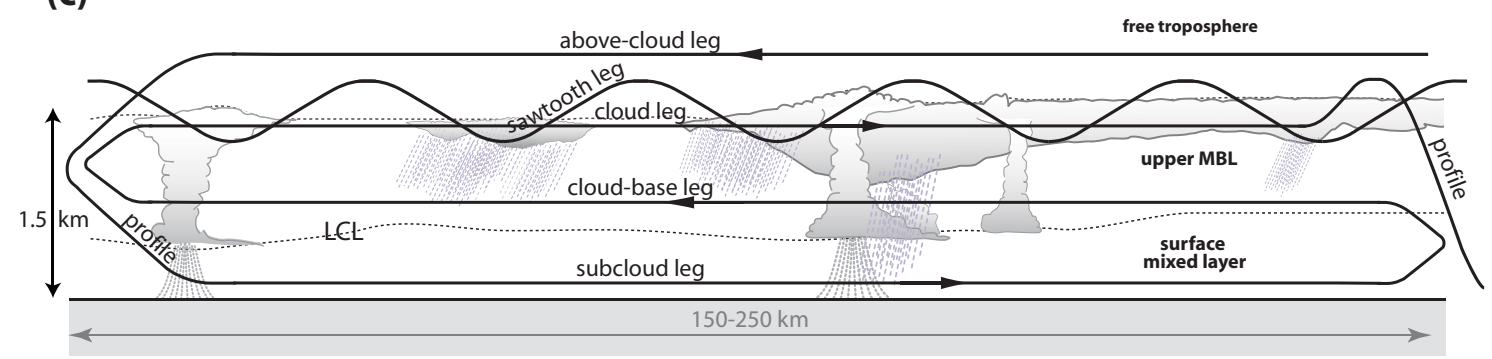

Fig. 7. POC-Drift mission flight plan. (a) schematic of plan view; (b) example POC-Drift misson flight track from C-130 Research Flight RF08 on 2 Nov 2008; (c) schematic cross section of boundary between open and closed cell regions showing sampling using long straight and level runs $150-250 \mathrm{~km}$ in length, profiles, and sawtooth sampling through the upper part of the MBL and lower troposphere. Due to its reduced range the BAe-146 sampled a subset of the C-130 flight plan when sampling POCs.

October 2008) it was possible to sample the same advected POC with two aircraft missions spaced approximately $12 \mathrm{~h}$ apart;

3. Stacked cloud and/or radiation missions in which one or two aircraft sample a cloudy boundary layer airmass, typically using stacked legs $50-100 \mathrm{~km}$ in length. For two-aircraft missions, the upper aircraft primarily served as a radiation/remote sensing platform and flew in the free troposphere. All the aircraft other than the C-130 carried out missions of this type. All Twin Otter missions were of this type, and additionally were carried out at the same location (at so-called "Point Alpha", $\left.20^{\circ} \mathrm{S}, 72^{\circ} \mathrm{W}\right)$;

4. Pollution Survey missions in which aircraft sampled within a few hundred $\mathrm{km}$ of the Peruvian and Chilean coasts, with the aim of characterizing the lower atmosphere in the vicinity of pollution source regions. These missions replaced the polluted Lagrangian missions which had been originally planned for VOCALSREx, because it became clear that Lagrangian missions starting around $20-25^{\circ} \mathrm{S}$ would not sample sufficiently close to the major pollution sources to capture the aging process. Emphasis was placed on sampling both within the MBL and in the lower free troposphere, but occasional profiles up to 3-4 km altitude were also employed. Figure 2 shows the typical locations of these flights. The BAe-146 and C-130 aircraft performed the bulk of the pollution survey sampling, with six flights dedicated to this mission type;

5. Intercomparison flights, either aircraft-aircraft (at several different flight levels both in and above the MBL) or to compare aircraft and ship measurements (with the aircraft flying at its lowest possible flight level, typically $150 \mathrm{~m}$ ). The summary of intercomparisons is given in Table 12.

Tables 6, 7, 8, 9, and 10 present the specific missions flown by the C-130, BAe-146, G-1, Do228, and Twin Otter respectively.

\subsection{Ship sampling}

\subsubsection{Peruvian R/V José Olaya}

Figure 8 shows the track of the R/V José Olaya during the VOCALS REx cruise (2-17 October 2008). A total of 133 radiosonde soundings were acquired at varying spatiotemporal intervals from 30 September to 17 October 2008. 
Table 9. Details of Do-228 aircraft missions conducted in the VOCALS Regional Experiment.

\begin{tabular}{|c|c|c|c|c|c|}
\hline \multirow[t]{2}{*}{ Flight } & \multirow[t]{2}{*}{ Date } & \multicolumn{2}{|c|}{ Times [UTC] } & \multirow[t]{2}{*}{ Mission/Location } & \multirow[t]{2}{*}{ Notes } \\
\hline & & $\mathrm{T} / \mathrm{O}$ & Land & & \\
\hline VA01 & Oct 26 & $14: 16$ & $17: 27$ & Test flight & \\
\hline VA02 & Oct 28 & $12: 49$ & $14: 30$ & Test flight & \\
\hline VA03 & Oct 30 & $11: 38$ & $15: 48$ & $\begin{array}{l}\text { Overfly RHB at } 19^{\circ} 35.5^{\prime} \mathrm{S}, \\
74^{\circ} 46.9^{\prime} \mathrm{W}\end{array}$ & Stacked cloud/radiation over RHB and FAAM BAe146 \\
\hline VA04 & Oct 31 & $11: 30$ & $15: 26$ & $20^{\circ} \mathrm{S}$ cross-section & To point alpha at $4800 \mathrm{~m}$ then west to $76^{\circ} \mathrm{W}$, retracing path \\
\hline VA05 & Nov 2 & $11: 54$ & $15: 11$ & Profiling, to $19.5^{\circ} \mathrm{S}, 74.5^{\circ} \mathrm{W}$ & $\begin{array}{l}\text { Six vertical profiles, cloud top- } 4800 \mathrm{~m} \text {, followed by spiral } \\
\text { descent and return to Arica at } 3400 \mathrm{~m}\end{array}$ \\
\hline VA06 & Nov 3 & 13:00 & $16: 36$ & Coastal pollution gradient & $\begin{array}{l}\text { Flew to Peruvian border at } 4000 \mathrm{~m} \text {, then followed same path as } \\
\text { FAAM BAe146 to DART buoy; back at } 3300 \mathrm{~m}\end{array}$ \\
\hline VA07 & Nov 4 & $11: 31$ & $15: 43$ & $20^{\circ} \mathrm{S}$ cross-section & As VA04 except return leg at 3400 and $3200 \mathrm{~m}$ \\
\hline VA08 & Nov 5 & 13:00 & $16: 11$ & $\begin{array}{l}\text { Profiling flight south to } \\
22^{\circ} 39^{\prime} \mathrm{S}, 71^{\circ} 10^{\prime} \mathrm{W}\end{array}$ & Profiling coastal pollution between cloud top and $4800 \mathrm{~m}$ \\
\hline VA09 & Nov 6 & $18: 35$ & $20: 14$ & Lidar test & Flew to point alpha and back between 4000 and $5000 \mathrm{~m}$ \\
\hline VA10 & Nov 9 & $13: 39$ & $17: 52$ & $20^{\circ} \mathrm{S}$ cross-section & as VA04 \\
\hline VA11 & Nov 10 & $11: 23$ & $15: 23$ & Loop south to $22.4^{\circ} \mathrm{S}$ & $4800 \mathrm{~m}$; overflight of FAAM BAe146 \\
\hline VA12 & Nov 12 & $11: 35$ & $12: 19$ & Flight aborted & Problem with aircraft \\
\hline VA13 & Nov 13 & $10: 05$ & $11: 45$ & Intercomparison with BAe-146 & Legs at $200 \mathrm{~m}-3 \mathrm{~km}$ altitude \\
\hline VA14 & Nov 13 & $12: 45$ & $16: 48$ & $20^{\circ} \mathrm{S}$ cross-section & As VA04 except return leg at $4200 \mathrm{~m}$ \\
\hline VA15 & Nov 14 & $13: 15$ & $16: 51$ & Vertical profiling to $22.5^{\circ} \mathrm{S}$ & 8 vertical profiles, $100-4800 \mathrm{~m}$ \\
\hline
\end{tabular}

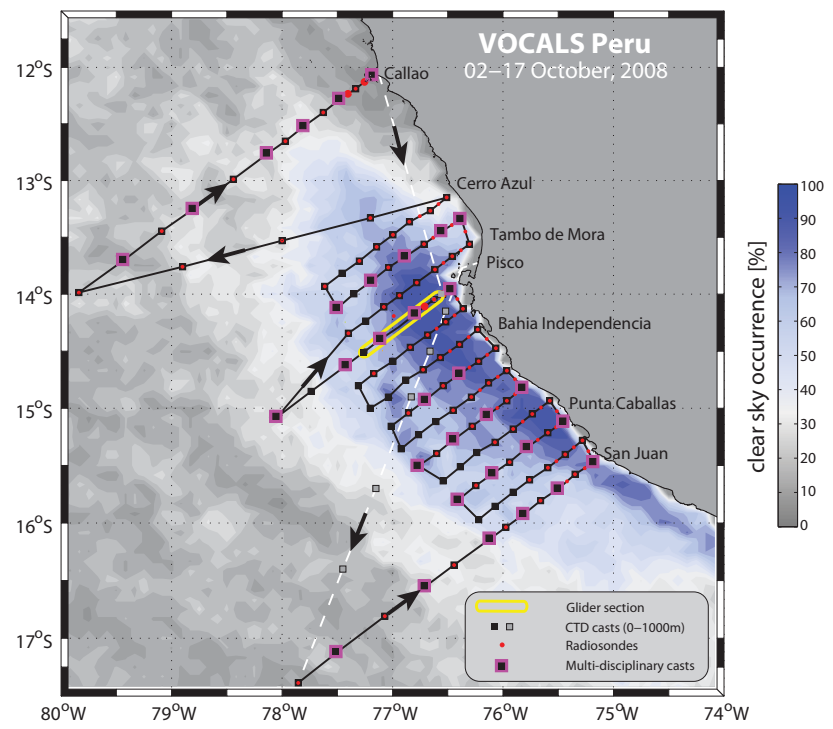

Fig. 8. Cruise track (black, with white for transit legs) and sampling from the IMARPE R/V José Olaya during the VOCALS Peru cruise (2-17 October 2008). The color contours show the Octobermean (1997-2004) daytime clear sky fraction determined using the SeaWIFS cloud clearing algorithm.

Launch sites were predominately within the upwelling zone, about $200 \mathrm{~km}$ from the coast of the Pisco-San Juan upwelling region. Temperature, salinity and currents were measured to characterize the physical properties of the upwelling plume and the associated thermal front. A cluster of 8 surface drifters were deployed across the upwelling front in order to study the advective and diffusive processes inside this feature. The glider (autonomous underwater vehicle) mission was designed to examine the high-resolution structure and dynamics of the upwelling plume and thermal front off Pisco between $10 \mathrm{~km}$ and $100 \mathrm{~km}$ from the coast. The distribution of biogeochemical and biological parameters as well as fish abundance were also sampled to study the feedback of ocean/atmosphere interactions on biological and fishery activity.

\subsubsection{NOAA R/V Ronald H. Brown}

Figure 9 shows the track of the NOAA R/V Ronald H. Brown (RHB) during the VOCALS REx cruise (25 October to 2 December 2008). The cruise was planned and carried out as two legs: Leg 1 took place between 29 September to 3 November 2008 (arriving in the VOCALS-REx domain on 24 October 2008) and the RHB spent the majority of the time stationed at the IMET and DART mooring where recovery and redeployment of the moorings took place; Leg 2 took place between 9 November and 2 December 2008 and involved mapping the structure of the upper ocean and observing the atmosphere exclusively in the VOCALS-REx domain.

After the RHB arrived in the VOCALS-REx domain, all of the sampling took place between $18^{\circ} \mathrm{S}$ and $22^{\circ} \mathrm{S}$. Both 
Table 10. Details of Twin Otter aircraft missions conducted in the VOCALS Regional Experiment.

\begin{tabular}{|c|c|c|c|c|c|}
\hline \multirow[t]{2}{*}{ Flight } & \multirow[t]{2}{*}{ Date } & \multicolumn{2}{|c|}{ Times [UTC] } & \multirow[t]{2}{*}{ Mission/Location } & \multirow[t]{2}{*}{ Notes } \\
\hline & & $\mathrm{T} / \mathrm{O}$ & Land & & \\
\hline 01 & Oct 16 & $14: 16$ & $17: 27$ & Stacked turbulence/aerosol/cloud & At Point Alpha $\left(20^{\circ} \mathrm{S}, 72^{\circ} \mathrm{W}\right) 15: 10-17: 50$ \\
\hline 02 & Oct 18 & $12: 49$ & $14: 30$ & Stacked turbulence/aerosol/cloud & At Point Alpha 12:15-15:00 \\
\hline 03 & Oct 19 & $11: 38$ & $15: 48$ & Stacked turbulence/aerosol/cloud & At Point Alpha 12:05-14:40 \\
\hline 04 & Oct 21 & $11: 30$ & $15: 26$ & Stacked turbulence/aerosol/cloud & At Point Alpha 12:10-14:50 \\
\hline 05 & Oct 22 & $11: 54$ & $15: 11$ & Stacked turbulence/aerosol/cloud & At Point Alpha 12:00-14:40 \\
\hline 06 & Oct 24 & 13:00 & $16: 36$ & Stacked turbulence/aerosol/cloud & At Point Alpha 12:15-15:00 \\
\hline 07 & Oct 26 & $11: 31$ & $15: 43$ & Stacked turbulence/aerosol/cloud & At Point Alpha 12:00-15:00 \\
\hline 08 & Oct 27 & 13:00 & $16: 11$ & Stacked turbulence/aerosol/cloud & At Point Alpha 15:55-19:00 \\
\hline 09 & Oct 29 & $18: 35$ & $20: 14$ & Stacked turbulence/aerosol/cloud & At Point Alpha 11:50-15:00 \\
\hline 10 & Oct 30 & $13: 39$ & $17: 52$ & Stacked turbulence/aerosol/cloud & At Point Alpha 11:50-15:00 \\
\hline 11 & Nov 1 & $11: 23$ & $15: 23$ & Stacked turbulence/aerosol/cloud & At Point Alpha 12:05-15:05 \\
\hline 12 & Nov 2 & $11: 35$ & $12: 19$ & Stacked turbulence/aerosol/cloud & At Point Alpha 11:55-15:00 \\
\hline 13 & Nov 4 & 10:05 & $11: 45$ & Stacked turbulence/aerosol/cloud & At Point Alpha 11:50-14:40 \\
\hline 14 & Nov 5 & 10:00 & $16: 50$ & Stacked turbulence/aerosol/cloud & At Point Alpha 11:50-15:00. Cloud/aerosol probe data failed \\
\hline 15 & Nov 8 & $12: 45$ & $16: 48$ & Stacked turbulence/aerosol/cloud & At Point Alpha 11:50-15:00 \\
\hline 16 & Nov 9 & $13: 15$ & $16: 51$ & Stacked turbulence/aerosol/cloud & At Point Alpha 11:50-15:05 \\
\hline 17 & Nov 10 & $13: 15$ & $16: 51$ & Stacked turbulence/aerosol/cloud & At Point Alpha 14:45-18:00 \\
\hline 18 & Nov 12 & $13: 15$ & $16: 51$ & Stacked turbulence/aerosol/cloud & At Point Alpha 11:50-15:15 \\
\hline 19 & Nov 13 & $13: 15$ & $16: 51$ & Stacked turbulence/aerosol/cloud & At Point Alpha 12:00-14:50 \\
\hline
\end{tabular}

Legs 1 and 2 involved studies of the ocean, the atmosphere, and their coupling as part of VOCALS-REx. Leg 1 focused primarily upon measurements at the IMET and SHOA buoys, while Leg 2 involved more surveying of mesoscale ocean features. The sampling strategy for Leg 2 was optimized during the "all-hands" meeting in Arica between legs, the adjustments being necessary because operational delays reduced the Leg 1 sampling by almost 10 days which compromised the mesoscale surveying during Leg 1. Coordinated sampling with research aircraft working from Arica and Iquique took place during both cruises, with the majority of coordinated sampling taking place during Leg 2 (see Tables 6 to 9 for details of RHB-aircraft cosampling.

A total of 210 radiosondes were obtained at $4 \mathrm{~h}$ intervals within the marine stratocumulus region. The ship sampled multiple times across relatively sharp transitions of cloud coverage including clear to broken to overcast stratocumulus cloud conditions. It was overcast approximately $80 \%$ of the time. Drizzle was prevalent: drizzle-containing cells with significant radar reflectivity $(Z>0 \mathrm{dBZ})$ were observed within a $60 \mathrm{~km}$ radius of the ship roughly half the time. The RHB research cruise for VOCALS-Rex was designed to address important aspects of both (1) aerosol-cloud-drizzle hypotheses and (2) coupled ocean-atmosphere hypotheses.

Aerosol-cloud-drizzle interactions vary in both space and time at a multitude of scales. The ship provided a platform to investigate in detail aerosol distributions and composition, including diurnal patterns during slow transects over much smaller regions of the marine boundary layer than is covered by the aircraft in a single hour. For this reason, the nearly 60 -day cruise provided measurements of marine aerosol with a greater range of statistical variability, more chemical detail (such as organic functional groups, see Hawkins et al., 2010), and highly accurate standards as references (such as ion chromatography) that are complementary to the aircraftbased data sets. In addition, the measurement of radon on the RHB permits an assessment of the time that airmasses have spent over the ocean. The RHB studies of aerosol properties provide a comprehensive basis for addressing the variability in physicochemical properties. These measurements also serve as the basis for comparison of the sources and composition of the aerosol particles, providing comprehensive information with which to compare to satellite-retrieved properties.

The main objectives of the oceanographic field work conducted from the R/V Ron Brown (Legs 1 and 2) were: (i) to map the mean and eddy (mesoscale/submesoscale) temperature, salinity and velocity distribution within the SEP's upper ocean during VOCALS-REx; (ii) to deploy Lagrangian floats and drifters within the SEP; (iii) to recover and re-deploy the STRATUS and DART moorings. The synoptic survey across the SEP region included the collection of $35 \mathrm{CTD}$ (Conductivity, Temperature, Depth profiles) up to $2000 \mathrm{~m}$ depth, and of 438 UCTD (Underway CTD) profiles, ranging between 200 and $800 \mathrm{~m}$ deep, to map the meridional distribution of properties across the SEP along three distinct latitude lines (Fig. 9). During the surveys, spatial and temporal sampling was increased to resolve a number of oceanic fronts and eddies, including 4 cyclones, 2 anticyclones, the coastal currents and upwelling front at $21.5^{\circ} \mathrm{S}$. Microstructure profiles to quantify mixing rates were obtained using a Vertical Microstructure Profiler (VMP) at 15 
Table 11. Details of POC sampling/missions conducted in the VOCALS Regional Experiment.

\begin{tabular}{|c|c|c|c|c|c|}
\hline \multirow[t]{2}{*}{ Aicraft } & \multirow[t]{2}{*}{ Flight } & \multirow[t]{2}{*}{ Date } & \multicolumn{2}{|c|}{ Times [UTC] } & \multirow[t]{2}{*}{ Details } \\
\hline & & & $\mathrm{T} / \mathrm{O}$ & Land & \\
\hline C-130 & RF02 & Oct 18 & 13:04 & $21: 27$ & Daytime mission. Sampling of rift-like feature at $21^{\circ} \mathrm{S}, 82.5^{\circ} \mathrm{W}$ \\
\hline BAe-146 & B409 & Oct 27 & 19:59 & 00:29 & $\begin{array}{l}\text { Late afternoon mission. POC edge sampled at } 21^{\circ} \mathrm{S}, 77.5^{\circ} \mathrm{W} \text {. First flight of } \\
\text { POC Lagrangian mission with C- } 130 \text { flight RF06 }\end{array}$ \\
\hline C-130 & RF06 & Oct 28 & $06: 20$ & $15: 10$ & $\begin{array}{l}\text { Night mission. Very clear POC edge sampled at } 18^{\circ} \mathrm{S}, 80^{\circ} \mathrm{W} \text {. Second flight of } \\
\text { POC Lagrangian mission with BAe-146 flight B } 409\end{array}$ \\
\hline C-130 & RF07 & Oct 31 & 06:03 & $14: 58$ & $\begin{array}{l}\text { Night mission. Sampling of recently-formed } \mathrm{POC} \text { at } 21.5^{\circ} \mathrm{S}, 80^{\circ} \mathrm{W} \text { which } \\
\text { was growing and spreading to the north. }\end{array}$ \\
\hline C-130 & RF08 & Nov 2 & 06:00 & $15: 20$ & $\begin{array}{l}\text { Night mission. Sampling of a pronounced microphysical boundary at } \\
22^{\circ} \mathrm{S}, 80^{\circ} \mathrm{W} \text { between a polluted tongue of stratocumulus and a very clean } \\
\text { airrmass with precipitating open cells to south. Pronounced difference in MBL } \\
\text { height across boundary. }\end{array}$ \\
\hline C-130 & RF09 & Nov 4 & 06:02 & $14: 54$ & $\begin{array}{l}\text { Night mission. POC sampling across a boundary between polluted } \\
\text { stratocumulus tongue and very clean airmass at } 22^{\circ} \mathrm{S}, 80^{\circ} \mathrm{W} \text {. Boundary less } \\
\text { well-pronounced than in other cases and overcast stratocumulus appeared to be } \\
\text { breaking up during flight. }\end{array}$ \\
\hline BAe-146 & B415 & Nov 5 & 09:12 & $14: 33$ & Early morning mission. Open cellular region sampled at $\sim 78^{\circ} \mathrm{W}$. \\
\hline BAe-146 & B416 & Nov 7 & $10: 32$ & $15: 27$ & Morning mission. Open cellular region sampled at $\sim 78^{\circ} \mathrm{W}$. \\
\hline BAe-146 & B420 & Nov 13 & 09:58 & $15: 13$ & Morning mission. POC sampled briefly at western point at $\sim 81^{\circ} \mathrm{W}$. \\
\hline C-130 & RF13 & Nov 13 & 13:00 & $21: 55$ & $\begin{array}{l}\text { Day mission, Extensive clearing near coast, then thick cloud with } \\
\text { recently-formed POC at } 19^{\circ} \mathrm{S}, 78^{\circ} \mathrm{W}\end{array}$ \\
\hline C-130 & RF14 & Nov 15 & 13:00 & 22:00 & Day mission, rift/clearing sampled, high $\mathrm{SO}_{2}$ just above $\mathrm{MBL}$ at $21^{\circ} \mathrm{S}, 80^{\circ} \mathrm{W}$ \\
\hline
\end{tabular}

Table 12. Details of the intercomparisons conducted VOCALS-REx.

\begin{tabular}{|c|c|c|c|c|c|c|}
\hline Platform & BAe-146 & G-1 & Twin Otter & Do-228 & RHB & Paposo \\
\hline C-130 & $\begin{array}{l}\text { 1. 10/31 } \\
\text { (RF07/B412) } \\
\text { 2. } 11 / 04 \\
\text { (RF09/B414) }\end{array}$ & $\begin{array}{l}\text { 1. } 10 / 23 \text { (RF04) } \\
\text { 2. } 11 / 04 \text { (RF09) }\end{array}$ & None & None & $\begin{array}{l}\text { 1. 10/25 (RF05, } \\
\text { IMET Buoy) } \\
\text { 2. 11/02 (RF08, } \\
\text { SHOA Buoy) } \\
\text { 3. 11/11 (RF12, } \\
\text { near SHOA buoy) }\end{array}$ & $\begin{array}{l}\text { 1. 11/9 (RF11, } \\
\text { along } 73 \mathrm{~W}) \\
\text { 2. } 11 / 11(\mathrm{RF} 12 \text {, } \\
\text { along } 73 \mathrm{~W})\end{array}$ \\
\hline BAe-146 & - & $\begin{array}{l}\text { 1. ground } \\
\text { comparison } \\
\text { 2. } 11 / 12(\mathrm{~B} 419)\end{array}$ & None & $\begin{array}{l}11 / 13 \\
\text { (B420/VA13) }\end{array}$ & $\begin{array}{l}\text { 1. 10/30 (near } \\
\text { SHOA Buoy) } \\
\text { 2. } 11 / 12 \text { (near } \\
\text { SHOA buoy) }\end{array}$ & None \\
\hline G-1 & - & - & $10 / 26$ & None & None & None \\
\hline Twin Otter & - & - & - & None & $\begin{array}{l}11 / 10 \text { (near } \\
\text { SHOA buoy) }\end{array}$ & None \\
\hline Do-228 & - & - & - & - & 10/30 VA03 & None \\
\hline RHB & - & - & - & - & - & None \\
\hline
\end{tabular}

different locations that included the centers and margins of several of the eddies/fronts. The velocity structure of the upper 300-500 m, along the ship track, was observed by the ship's Acoustic Doppler Current Profiler (ADCP) - thus pro- viding direct observations of the velocity field within the eddies, fronts and boundary currents to complement the property measurements. In addition to the synoptic measurements conducted during VOCALS-REx, the deployment of 


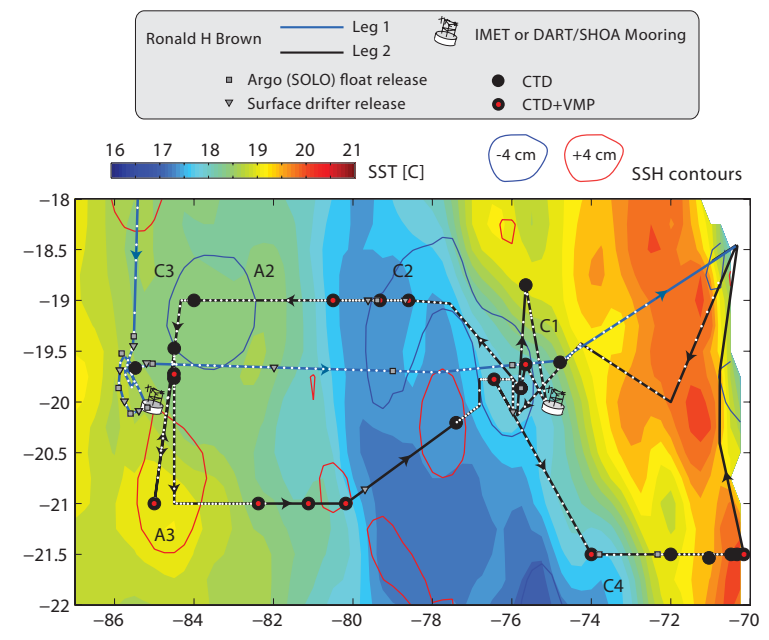

Fig. 9. Cruise tracks for Legs 1 and 2 of the NOAA R/V Ron Brown during VOCALS-Rex superimposed on the sea-surface temperature (SST) and sea-surface height (SSH) from November 18th 2008 (middle of Leg 2; courtesy of P. Gaube and D. Chelton, OSU). The 438 underway CTDs (UCTD) are overlaid as white dots on the two tracks. Also shown are the locations of the 35 CTDs and 15 VMP (microstructure) profiles as well as those where 19 surface drifters and 10 profiling SOLO floats were deployed. Several of the sampled cyclones and anticyclones are indicated by a $\mathrm{C}$ and $\mathrm{A}$, respectively, followed by a sequential number.

10 profiling Lagrangian floats (SOLO floats, equipped with an oxygen sensor) and 19 surface drifters - some in eddies and some throughout the SEP - were designed to provide long-term context to the synoptic measurements - together with the instruments recovered and re-deployed on the IMET/STRATUS and DART buoys.

\section{Satellite datasets produced specifically for VOCALS-REX}

\subsection{Geostationary Operational Environmental Satellites, GOES-10}

\subsubsection{Visible Infrared Solar-Infrared Split Window Technique (VISST)}

Cloud and radiation parameters at 4-km resolution were derived from the tenth Geostationary Operational Environmental Satellite imager (GOES-10), located at $60^{\circ} \mathrm{W}$, using techniques developed at NASA Langley Research Center (LaRC). The GOES-10 data were analyzed every half hour for the region bounded by $10^{\circ} \mathrm{S}, 30^{\circ} \mathrm{S}, 65^{\circ} \mathrm{W}$, and $90^{\circ} \mathrm{W}$ for the period between 11 September and 1 December 2008 and provided in near-real time for mission planning and analysis. Clouds were detected using the method of Minnis et al. (2008) and cloud properties were retrieved during the daytime using the Visible Infrared Shortwave-infrared
Split-window Technique (VISST). At night, cloud properties were retrieved using the Shortwave-infrared Infrared Splitwindow Technique (SIST). The methods are described in detail for application to MODerate-resolution Imaging Spectroradiometer (MODIS) data by Minnis et al. $(2008,2010)$. The VISST uses the $0.65,3.9,10.8$, and $12.0 \mu \mathrm{m}$ channels, while the SIST uses the same channels minus the $0.65 \mu$ m data. The GOES-10 $0.65 \mu \mathrm{m}$ channel was calibrated against the Terra MODIS $0.64 \mu \mathrm{m}$ channel using the technique of Minnis et al. (2002). The available derived parameters and means of accessing the data are similar to those described by (Palikonda et al., 2006). Both pixel-level and $0.5 \times 0.5^{\circ}$ averages are available each hour in image and digital form ${ }^{2}$. The VISST and SIST assume that only single-layer clouds are in a given pixel. In addition to the standard approach described by Minnis et al. (2010), cloud-top height and pressure were also retrieved using the method described by Zuidema et al. (2009). One additional parameter, a multilayer cloud identifier was computed for each pixel using the approach of Pavolonis and Heidinger (2004). In addition to the cloud properties, spectral radiances and estimates of the top-of-atmosphere shortwave albedo and outgoing longwave radiation are included.

Figure 10 shows an example of three parameters for a GOES-10 image taken at 15:45 UTC, 27 October 2010. The pseudo-color RGB image (Fig. 10a) shows low clouds in the orange and peach shades with high cirrus clouds appearing white, gray, and magenta. The effective cloud temperatures $T_{\mathrm{c}}$ are displayed in Fig. 10b for an abbreviated range of $273 \mathrm{~K}<T_{\mathrm{c}}<300 \mathrm{~K}$ to better show variations in stratocumulus cloud temperatures. Temperatures less than $273 \mathrm{~K}$ are indicated in the maroon shade. For this case, $T_{\mathrm{c}}$ ranges from $274 \mathrm{~K}$ to $284 \mathrm{~K}$ for the marine stratocumulus clouds. Smaller values are evident where thin cirrus clouds occur over the low clouds. Cloud optical depths (Fig. 10c) range from less than 1 at some cloud edges to more than 40 near $18^{\circ} \mathrm{S}, 78^{\circ} \mathrm{W}$. The VISST-derived droplet effective radius, re, (Fig. 10d) varies from about 7 to $25 \mu \mathrm{m}$ across the scene with most of the largest values occurring around the edges of the POCs. The smallest droplets are mostly near the coast. The pixel-level products, exemplified in Fig. 10a-d, are used to produce $0.5 \times 0.5^{\circ}$ regional means at each half hour for many of the cloud and radiation parameters (Palikonda et al., 2006). Examples of $0.5 \times 0.5^{\circ}$ regionally-averaged cloud top-height $Z_{\mathrm{t}}$ and liquid water path (LWP) are shown in Fig. 10e, f. The $Z_{\mathrm{t}}$ values estimated as in Minnis et al. (2010) range from less than $1 \mathrm{~km}$ up to more than $3 \mathrm{~km}$ in the southwestern portion of the domain. Higher clouds near the center of the domain correspond to the thin cirrus clouds over the stratocumulus deck. The heights based on the Zuidema et al. (2009) technique are generally lower (not shown). The cloud LWP ranges from less than $50 \mathrm{~g} \mathrm{~m}^{-2}$ along the coast to over $200 \mathrm{~g} \mathrm{~m}^{-2}$ near the center of the domain. The LaRC

\footnotetext{
${ }^{2}$ Available from http://www-angler.larc.nasa.gov/cgi-bin/site/ showdoc?mnemonic $=$ VOCALS
} 

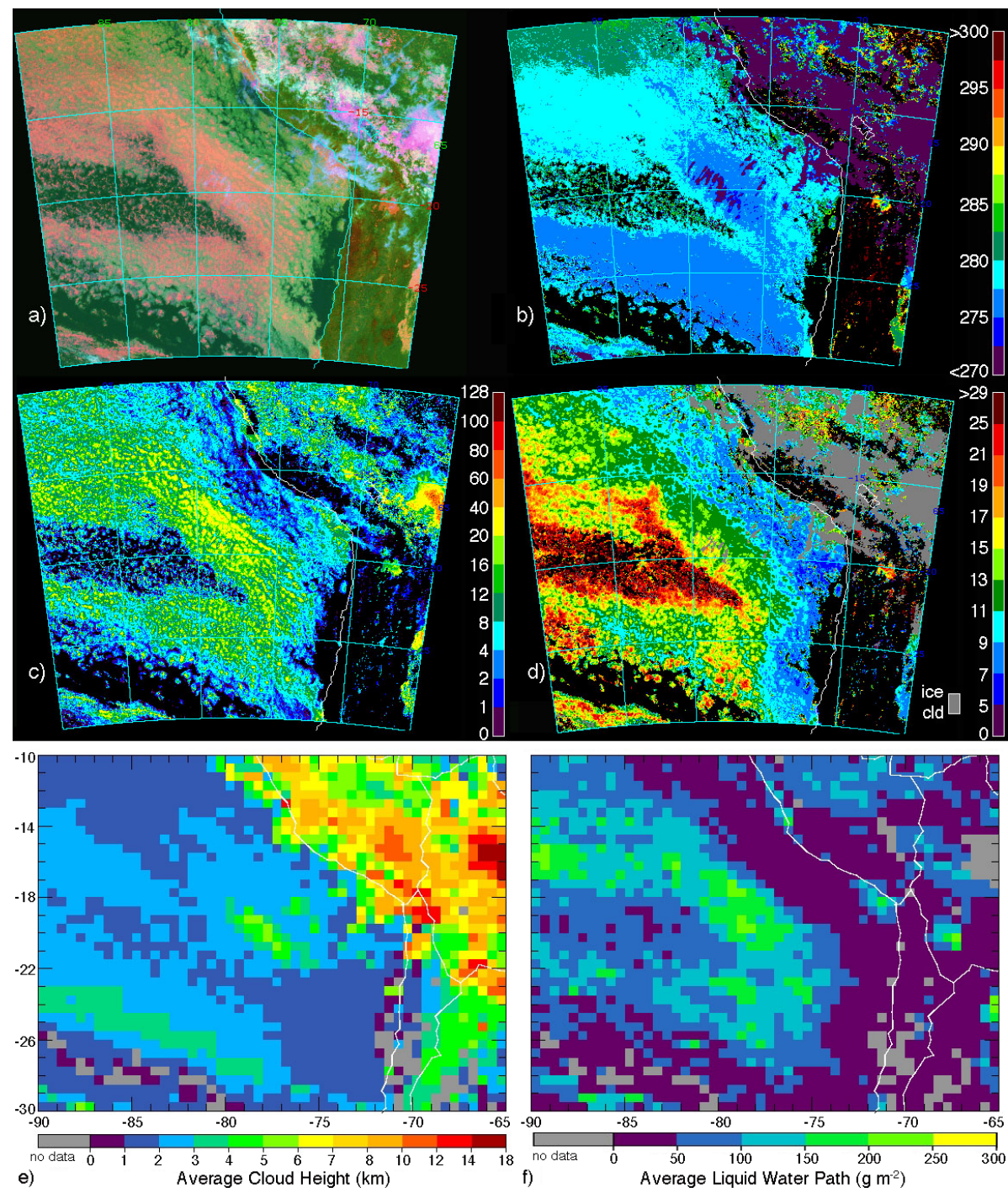

Fig. 10. GOES-10 imagery and retrieved cloud parameters, 15:45 UTC, 27 October 2008: (a) pseudocolor RGB image; (b) cloud effective temperature $[\mathrm{K}]$; (c) cloud optical depth; (d) cloud liquid water droplet effective radius $[\mu \mathrm{m}]$. Regional $\left(0.5 \times 0.5^{\circ}\right)$ average cloud properties, (e) cloud top height, and (f) cloud liquid water path for the same time.

cloud properties are based on near-real time retrievals. A refined dataset using the latest GOES-10 calibrations, a higher resolution sea surface temperature dataset, and algorithm updates is being generated to provide a more accurate set of cloud properties for stratocumulus research and for comparison with the other experiment measurements to better define the uncertainties in the satellite products.

\subsubsection{Gridded cloud cover product from the University of Manchester/Met Office}

Thermal infrared data from GOES-10 (Channel 4, $10.7 \mu \mathrm{m}$ ), converted to netCDF format and archived on the VOCALS data archive (see Sect. 8), have been used to generate a dataset documenting the variability in cloud amount during the VOCALS-REx period. The GOES-10 data were analyzed between 1 October and 8 December 2008 in a region from $3.5-31.5^{\circ} \mathrm{S}$ and $68.5-96.5^{\circ} \mathrm{W}$. Note that this is a more extensive region than for the VISST GOES-10 products described above. Clouds are classified on all available GOES-10 scans (typically every 15 to $30 \mathrm{~min}$ ) at a horizontal resolution of $4 \mathrm{~km}$, and cloud cover fractions are gridded at $0.25 \times 0.25^{\circ}$ resolution. Further details are given in Abel et al. (2010), and the dataset is available on the VOCALS archive, described below.

\subsection{MODIS subset}

A dedicated subset of MODIS imagery from NASA's Terra and Aqua satellites for the VOCALS-REx study region is 
available for browsing on the MODIS Rapidfire website http://rapidfire.sci.gsfc.nasa.gov/subsets/?subset=VOCALS.

\section{Coordinated modeling for VOCALS-REx}

\subsection{Overview of the VOCALS modeling program}

An overarching goal of VOCALS is to improve model simulations of key climate processes using the SEP as a testbed, particularly in coupled models that are used for climate change projection and ENSO forecasting. Hence, REx was developed in close coordination with the VOCALS modeling program, whose main goals are:

1. Understanding and reducing the warm SEP SST bias near the coast and excessive interhemispheric symmetry in the eastern tropical Pacific present in most coupled climate models.

2. Using the SEP as a testbed for better simulation of boundary layer cloud processes and aerosol-cloud interaction, including the relative roles of natural and anthropogenic aerosol sources and their impact on cloud optical properties (coverage, thickness, and droplet size).

3. Improving the understanding and simulation of oceanic budgets of heat, salinity, and nutrients in the SEP and their feedbacks on the regional climate.

4. Elucidating interactions between the SEP and other parts of Earth's climate system, including the South American continent, the Pacific circulation and ENSO.

The VOCALS modeling vision is based on the concept of a multiscale hierarchy of models, both in time and space. This is motivated by the multiscale nature of processes in the SEP and the multiscale hierarchy of VOCALS observations, including REx, extended in-situ and satellite data. In this spirit, one VOCALS modeling goal is to test models used for long-term climate projection as rigorously as possible by applying them on a different timescale, namely the short period of intensive data gathering during REx, by testing them in a weather forecasting mode. Another goal is to compare observations with models of various horizontal and vertical resolutions, e.g. higher-resolution regional models vs. coarserresolution global models. A third goal is to test and apply small-scale process models, e.g. large-eddy simulation (LES) models of the cloud-topped boundary layer, which can inform our physical understanding and help guide the development of parameterizations for larger-scale models.

Many aspects of REx were designed to facilitate these modeling goals. The atmospheric observation strategy included repeated airborne and ship-based measurements along one transect, $20^{\circ} \mathrm{S}$, to facilitate comparison with global and regional atmospheric models used in forecast mode and to provide a rough climatology that could be compared with a broader group of coupled ocean-atmosphere models. All aircraft included cloud physics, turbulence and aerosol/chemical composition measurements for testing the representation of aerosol/cloud interaction in models; the Wyoming Cloud Radar on the C-130 also added precipitation profiles into this dataset. This integrated suite of measurements provides a strong constraint on simulations of SEP clouds and aerosols. Synthesis papers by Bretherton et al. (2010) (boundary layer and physical cloud properties) and Allen et al. (2011) (aerosol and chemical composition) summarize the results of the REx $20^{\circ} \mathrm{S}$ measurements in multiplatform $20^{\circ} \mathrm{S}$ synthesis datasets that will be part of the EOL VOCALS data archive and are designed to be convenient for comparison with large-scale models. Modeling studies by Rahn and Garreaud (2010a,b) and Abel et al. (2010) focus on comparison with REx $20^{\circ} \mathrm{S}$ measurements. The VOCALS assessment (see Sect. 6.3) was also conceived as an integrated part of REx, and will make use of the REx $20^{\circ} \mathrm{S}$ synthesis datasets.

The REx POC missions were designed for comparison with large-domain LES of cloud-aerosol-precipitation interaction, and modeling papers utilizing these REx datasets are already emerging, e.g. Wang et al. (2010).

REx ship-based sampling of mesoscale ocean eddies was also envisioned to complement and test a regional eddyresolving ( $5 \mathrm{~km}$ resolution) ocean model run in data assimilation mode; such modeling efforts are underway.

\subsection{Real-time modeling during REx}

Several modeling groups supported VOCALS-REx mission planning and field data interpretation through provision of plots from real-time forecasts. This also provided those groups a good opportunity to evaluate their models in the field. These forecast products are archived in the VOCALSREx Field Data Catalog ${ }^{3}$; they remain a useful "quick-look" resource. They include plots of simulated regional meteorological fields, vertical profiles, trajectories and cross-sections of selected fields and chemical constituents, especially along $20^{\circ} \mathrm{S}$, and some regional zonal cross-sections through the upper ocean.

A synopsis of contributed and archived real-time products follows.

\subsubsection{UKMO}

The UK Met Office (UKMO) submitted $20^{\circ} \mathrm{S}$ cross-sections and horizontal maps of a variety of fields from their operational weather forecast model, the Unified Model (UM), run at $40 \mathrm{~km}$ resolution globally, and from a $17 \mathrm{~km}$ resolution regional version of the UM nested inside their global model. In addition they contributed real-time forecasts from their Numerical Atmospheric Dispersion Modeling Environment

\footnotetext{
${ }^{3}$ Available at http://catalog.eol.ucar.edu/vocals/
} 
(NAME) dispersion/chemical transport model, also run at $17 \mathrm{~km}$ horizontal resolution.

\subsubsection{ECMWF}

The European Center for Medium-Range Weather Forecasts (ECMWF) global forecast system, run at T399 and T799 resolution, provided selected fields along $20^{\circ} \mathrm{S}$ and a regional cloud analysis. High resolution analyses are available for the REx period through the Year of Tropical Convection (YoTC) project $^{4}$.

\subsubsection{NCEP}

A variety of fields were archived from short-range operational global weather forecasts by the US National Centers for Environmental Prediction (NCEP), run at approximately $50 \mathrm{~km}$ resolution.

\subsubsection{NRL}

The Naval Research Laboratory (NRL) contributed real-time forecasts with their COAMPS (Coupled Ocean Atmosphere Mesoscale Prediction System) regional model using three nested grids (with resolutions of 45,15 and $5 \mathrm{~km}$, with the $15 \mathrm{~km}$ domain extending over the entire REx region). Plots include cloud and lower-tropospheric meteorological fields.

\subsubsection{U. Chile}

The University of Chile contributed plots of cloud and boundary layer fields from short-range forecasts with their version of the Weather Research and Forecasting (WRF) regional model run at $25 \mathrm{~km}$ resolution.

\subsubsection{UW trajectories}

Rhea George of the University of Washington plotted a variety of short-range forward and back isobaric and threedimensional trajectories from selected points and altitudes along the $20^{\circ} \mathrm{S}$ line, based on NCEP GFS wind analyses and short-range forecasts.

\subsubsection{FLEXPART particle dispersion model}

The FLEXPART ${ }^{5}$ Lagrangian particle dispersion model (Stohl et al., 2005), with a horizontal resolution of $0.5 \times 0.5^{\circ}$, and 26 vertical levels, was driven by GFS forecast winds. Millions of passive tracer particles in FLEXPART were continuously released, corresponding to point and distributed sources of South American anthropogenic and volcanic $\mathrm{SO}_{2}$ transported both by the resolved GFS winds and parameterized subgrid motions, until they were removed from the

\footnotetext{
${ }^{4}$ See http://www.ucar.edu/yotc/

${ }^{5}$ Available at http://www.esrl.noaa.gov/csd/metproducts/ flexpart/
}

simulation after 10 days. The resulting tracer concentrations should be regarded as excesses above any background associated with other more broadly based $\mathrm{SO}_{2}$ emission.

\subsubsection{Ocean state}

Both ECMWF and NCEP also provided selected zonal crosssections of upper ocean temperature and salinity from their operational coupled modeling systems.

\subsection{Model intercomparison studies for Rex}

Two model intercomparison studies have been organized in coordination with REx. The first was the Pre-VOCALS Assessment or PreVOCA (Wyant et al., 2010). It was designed to assess the skill of current global and regional atmospheric models in forecasting subtropical South East Pacific cloud and marine boundary layer (MBL) characteristics in preparation for REx. The 15 participating models represented the state of the art in simulation of the SE Pacific and other boundary-layer cloud regimes. They simulated the month of October 2006 and were compared in the region from $40^{\circ} \mathrm{S}$ to the equator and from $110^{\circ} \mathrm{W}-70^{\circ} \mathrm{W}$. Satellite datasets and rawinsondes from research cruises in the region were used for validation. Each model was run in some form of "forecast mode". Global models were initialized using a global analysis and compared based on short-range forecasts, while regional models were continuously forced at their boundaries using reanalysis data. A few models showed considerable skill in reproducing the monthly mean, day-to-day variability and diurnal cycle of cloud cover and MBL structure across the region, though all models had a low bias in MBL inversion height near the Chilean coast.

PreVOCA was designed to prepare VOCALS modeling groups for a more ambitious followon, the VOCALS assessment or VOCA ${ }^{6}$ based on the REx period of 15 October-15 November 2008. This assessment, which is ongoing, makes use of the extensive in-situ data (especially along 20S) to test chemical transport, aerosol and drizzle processes in simulations of the SE Pacific regions, as well as evaluating the time-varying cloud and MBL structure. Both global and regional climate models with chemical transport capabilities are participating. Global models each use their own chemical emissions inventory; a custom-designed regional emissions inventory was developed by Dr. Scott Spak of U. Iowa for use in regional models. Of particular interest is whether such models can simulate the observed offshore gradients of accumulation model aerosol concentration and cloud droplet concentration in the boundary layer. This is timely, since many global climate models have recently implemented representations of aerosol indirect effects on cloud properties.

\footnotetext{
${ }^{6}$ See http://www.atmos.washington.edu/ mwyant/vocals/ model/VOCA_Model_Spec.htm
} 


\section{VOCALS data management}

The NCAR/EOL provided data management support, coordination, and a long-term archive for VOCALS datasets. Details regarding VOCALS Data Management can be found on the VOCALS Project web page ${ }^{7}$. This web page contains the VOCALS data policy, instructions for data submission, relevant documentation, links to related projects data, and access to the distributed VOCALS long-term archive [i.e. Master List (ML) of VOCALS International Datasets]. The ML contains direct access to all datasets organized by data category and data source site with associated dataset documentation. In addition, the VOCALS-Rex Field Catalog 8 used during the field phase to provide operations and mission/scientific reports, operational and preliminary research imagery/products is available as a browse tool for use by researchers in the post-field analysis phase and is included as part of the archive.

\section{Conclusions}

The VOCALS Regional Experiment (VOCALS-REx) was an international field experiment designed to examine critical aspects of the coupled climate system of the Southeast Pacific region. VOCALS-REx took place during October and November 2008 in a domain $69-86^{\circ} \mathrm{W}, 12-31^{\circ} \mathrm{S}$. Sampling with a variety of platforms including two ship, five research aircraft, land sites and two instrument moorings will ensure that researchers have a number of different observational angles with which to test the VOCALS hypotheses. The purpose of this paper is to bring together in one document the scientific goals, the platforms and instrumentation, and the sampling strategies employed during the program. It is hoped that this will serve the VOCALS research community by providing a central location that describes the essence of the field program. Perhaps more importantly, we hope that it will help to provide an important legacy that will be available to researchers over the coming years.

\section{Appendix A}

\section{Acronyms used in this manuscript}

$\begin{array}{ll}\text { AMS } & \text { Aerosol Mass Spectrometer } \\ \text { BAe-146 } & \text { FAAM British Aerospace BAe-146 research } \\ & \text { aircraft } \\ \text { C-130 } & \begin{array}{l}\text { NSF/NCAR Lockheed C-130Q research } \\ \text { aircraft }\end{array} \\ \text { CAPS } & \begin{array}{l}\text { Cloud Aerosol And Precipitation } \\ \text { Spectrometer }\end{array}\end{array}$

\footnotetext{
${ }^{7}$ Available at http://www.eol.ucar.edu/projects/vocals/dm/index. html

${ }^{8}$ Located at http://catalog.eol.ucar.edu/vocals/
}

$\mathrm{CCN}$

$\mathrm{CN}$

Ultrafine $\mathrm{CN}$

CPC

CTD

CUpEx

DART/DB

DMS

DMSP

Do-228

DOE

EDGAR

FAAM

FIMS

G-1

IMARPE

IMET/STRATUS/

IB

MAX-DOAS

MBL

NCAR EOL

NERC

OPC

PAN

PCASP

POC

PSAP

PTRMS

RHB

SEM-EDX

SEP

SHOA

SMPS, DMPS

SP2

SST

STXM-NEXAFS

TDMA, TSEMS

TRAC

UCTD

VAMOS

VM-ADCP

VOCALS

WHOI
Cloud Condensation Nuclei, particles that nucleate at a given instrumental water vapor supersaturation, generally a fraction up to a few percent supersaturation.

Climate Variability and Predictability, component of World Climate Research

Programme

Condensation Nuclei, particle concentration

larger than given diameter, ca. $10 \mathrm{~nm}$. Condensation Nuclei, particle concentration

larger than given diameter, ca. $3 \mathrm{~nm}$.

Condensation Particle Counter, instrument to

measure $\mathrm{CN}$

Conductivity, Temperature, Depth

measurement

Chilean Upwelling Experiment

Deep-ocean Assessment and Reporting of

Tsunamis, buoy site

Dimethyl sulfide

Dimethylsulfonium propionate

NERC Dornier, DO-228 research aircraft

Department of Energy

Emission Database for Global Atmospheric

Research

Facility for Airborne Atmospheric

Measurements (United Kingdom)

Fast Integrated Mobility Spectrometer

DoE Gulfstream-1 research aircraft

Instituto del Mar del Per

Improved Meteorology buoy

Multi-Axis Differential Optical Absorption Spectroscopy

Marine Boundary Layer

National Center for Atmospheric Research

Earth Observation Laboratory

Natural Environment Research Council

Optical Particle Counter

Peroxy acetylnitrate

Passive Cavity Aerosol Spectrometer Probe

Pocket of Open Cells

Particle Soot Absorption Photometer

Proton transfer reaction mass spectroscopy

NOAA Research Vessel Ronald H. Brown

Scanning Electron Microscopy Energy

Dispersive X-ray

South East Pacific

Servicio Hidrogfico y Oceanogrfico de la

Armada de Chile buoy

Scanning Mobility Particle Sizer or

Differential Mobility Particle Sizer

Single Particle Soot Photometer

Sea Surface Temperature

Scanning Transmission X-ray Microscopy

Near Edge X-ray Absorption Fine Structure

Tandem Differential Mobility Analyzer,

Tandem Scanning Electrical Mobility System

Time Resolved Aerosol Sampler

Underway Conductivity, temperature, depth measurement

Variability of the American Monsoon Systems

Vessel Mounted Acoustic Doppler Current

Profiler

VAMOS Ocean-Cloud-Atmosphere-Land

Study

Woods Hole Oceanographic Institute 
Acknowledgements. It is practically impossible to acknowledge all the people who have contributed to VOCALS, but we can try to pay tribute to the various groups that have dedicated their resources, efforts, sweat and tears to the planning and execution of the program. First, we need to thank the teams led by Bob Weller at WHOI that deployed and maintained with annual cruises the IMET buoy which has provided almost a decade of high quality meteorological, radiation and oceanographic measurements. Thanks to Chris Fairall and coworkers at ESRL, and the scientists involved in the EPIC Stratocumulus cruise, these ship-borne data have led to a wealth of scientific data. We are extremely grateful to the support staff, crew and scientists who helped make the VOCALS-REx a success. These include the PIs, support scientists and crews of the six aircraft platforms (the NSF/NCAR C-130, the UK FAAM BAe-146, the DoE G-1, the CIRPAS Twin Otter, the UK NERC Dornier 228, and, in the 2010 CUpEx phase, the Chilean DGAC King Air), the two ships (the NOAA Ronald H. Brown, and the Peruvian IMARPE José Olaya), and the land stations at Iquique and Paposo. The NCAR Earth Observing Laboratory is thanked for their dedication to coordinating and executing field logistics and data archive support for VOCALS REx. The cooperation of hosts and collaborators in Chile and Peru who provided various critical facilities and support during REx is gratefully acknowledged. These include dedicated staff from the Chilean Weather Service (DMC), Ana Maria Cordova at Universidad de Valparaiso, Ricardo Muñoz, José Rutllant and fellow students at Universidad de Chile, Rosalino Fuenzalida, and fellow staff and students at Universidad Arturo Prat, Iquique, Chile; Yamina Silva at Instituto Geofísico del Perú, Lima and Boris Dewitte at Laboratoire d'Etudes en Géophysique et Océanographie Spatiales (LEGOS), Toulouse, France. Sounding operations were led by Tim Lim and quality control by Kate Young, both of NCAR/EOL. We also thank the Natural Environment Research Council, UK, for supporting the UK University contribution to VOCALS, and to FAAM, Directflight Ltd., Avalon Engineering Ltd, and ARSF, for providing the BAe146 and Dornier-228 aircraft respectively. Without the untiring efforts of the staff of these Facilities the science objectives of VOCALS would not have been met. The European Southern Observatory (ESO) are thanked for their help and support for measurements at Paranal. The NASA Langley GOES-10 analyses were supported by the NASA Modeling, Analysis, and Prediction Program and the DoE Atmospheric Radiation Measurement Program Agreement DE-AI02-07ER64546.

It is also a great pleasure to acknowledge the program managers in the US, particularly Walter Robinson from NSF and Jin Huang from NOAA whose support and guidance has been invaluable throughout.

Funding for VOCALS-REx was provided through the following grants: US National Science Foundation grants OCE07-44245, ATM-0934275, ATM0748012, ATM-0749011, ATM-0746685, AGS-0745337, ATM-0744636, ATM-0839872, ATM-0749088, ATM-0745702, ATM-0745986, OCE-0744245 and OCE-0741917; US National Oceanic and Atmospheric Administration grants NA08OAR4320899, NA09OAR4310206, NA070AR4310282, NA08OAR4310597, NA08OAR4310566, and GC08-252b; cooperative agreements between NOAA and NSF to fund logistics, operations and data archiving funded through NOAA grants NA07OAR4310267, NA06OAR4310119, and NA07OAR4310248; the US Office of Naval Research grants PE 0602435, N000140810437, and N000140810465; the Chilean
FONDECYT grants 1109004 and 1090412; the Swedish Research Council for Environment, Agricultural Sciences and Spatial Planning grant 2007-1008; The Met Office (UK); the UK Natural Environment Research Council grants NE/F019874/1 and NE/F018592/1; NSF-NCAR Cooperative Agreement: 0301213 Amendment 64 funded VOCALS Field Support; Meteo France.

Edited by: G. Feingold

\section{References}

Abel, S. J., Walters, D. N., and Allen, G.: Evaluation of stratocumulus cloud prediction in the Met Office forecast model during VOCALS-REx, Atmos. Chem. Phys., 10, 10541-10559, doi:10.5194/acp-10-10541-2010, 2010.

Ackerman, A. S., Kirkpatrick, M. P., Stevens, D. E., and Toon, O. B.: The impact of humidity above stratiform clouds on indirect aerosol climate forcing, Nature, 432, 1014-1017, 2004.

Allen, G., Coe, H., Clarke, A., Bretherton, C., Wood, R., Abel, S. J., Barrett, P., Brown, P., George, R., Freitag, S., McNaughton, C., Howell, S., Shank, L., Kapustin, V., Brekhovskikh, V., Kleinman, L., Lee, Y.-N., Springston, S., Toniazzo, T., Krejci, R., Fochesatto, J., Shaw, G., Krecl, P., Brooks, B., McKeeking, G., Bower, K. N., Williams, P. I., Crosier, J., Crawford, I., Connolly, P., Covert, D., and Bandy, A. R.: Southeast Pacific atmospheric composition and variability sampled along $20^{\circ} \mathrm{S}$ during VOCALS-REx, Atmos. Chem. Phys. Discuss., 11, 681-744, doi:10.5194/acpd-11-681-2011, 2011.

Andreae, M. O. and Merlet, P.: Emission of trace gases and aerosols from biomass burning, Global Biogeochem. Cy., 15, 955-966, 2001.

Avey, L., Garrett, T. ., and Stohl, A.: Evaluation of the aerosol indirect effect using satellite, tracer transport model, and aircraft data from the International Consortium for Atmospheric Research on Transport and Transformation,, J. Geophys. Res., 112, D10S33, doi:10.1029/2006JD007581, 2007.

Bennartz, R.: Global assessment of marine boundary layer cloud droplet number concentration from satellite, J. Geophys. Res., 112, D02201, doi:10.1029/2006JD007547, 2007.

Brenguier, J.-L. and Wood, R.: Observational strategies from the micro to meso scale, in: Perturbed clouds in the climate system, MIT Press, 2009.

Bretherton, C. S., Uttal, T., Fairall, C. W., Yuter, S. E., Weller, R. A., Baumgardner, D., Comstock, K., and Wood, R.: The EPIC 2001 stratocumulus study, B. Am. Meteor. Soc., 85, 967-977, 2004.

Bretherton, C. S., Wood, R., George, R. C., Leon, D., Allen, G., and Zheng, X.: Southeast Pacific stratocumulus clouds, precipitation and boundary layer structure sampled along $20^{\circ} \mathrm{S}$ during VOCALS-REx, Atmos. Chem. Phys., 10, 10639-10654, doi:10.5194/acp-10-10639-2010, 2010.

Brioude, J., Cooper, O. R., Feingold, G., Trainer, M., Freitas, S. R., Kowal, D., Ayers, J. K., Prins, E., Minnis, P., McKeen, S. A., Frost, G. J., and Hsie, E.-Y.: Effect of biomass burning on marine stratocumulus clouds off the California coast, Atmos. Chem. Phys., 9, 8841-8856, doi:10.5194/acp-9-8841-2009, 2009.

Caldwell, P., Wood, R., and Bretherton, C. S.: Mixed-layer budget analysis of the diurnal cycle of entrainment in SE Pacific stratocumulus, J. Atmos. Sci., 62, 3775-3791, 2005. 
Chand, D., Hegg, D. A., Wood, R., Shaw, G. E., Wallace, D., and Covert, D. S.: Source attribution of climatically important aerosol properties measured at Paposo (Chile) during VOCALS, Atmos. Chem. Phys., 10, 10789-10801, doi:10.5194/acp-1010789-2010, 2010.

Colbo, K. and Weller, R.: The variability and heat budget of the upper ocean under the Chile-Peru stratus, J. Marine. Res., 65, 607-637, 2007.

Colbo, K. and Weller, R.: Accuracy of the IMET Sensor Package in the Subtropics, J. Atmos. Ocean. Tech., 9, 1867-1890, 2009.

Comstock, K., Bretherton, C. S., and Yuter, S.: Mesoscale variability and drizzle in Southeast Pacific stratocumulus, J. Atmos. Sci., 62, 3792-3807, 2005.

Comstock, K., Yuter, S. E., Wood, R., and Bretherton, C. S.: The three dimensional structure and kinematics of drizzling stratocumulus, Mon. Weather Rev., 135, 3767-3784, 2007.

deSzoeke, S. P. and Xie, S. P.: The Tropical Eastern Pacific seasonal cycle: Assessment of errors and mechanisms in IPCC AR4 coupled ocean-atmosphere general circulation models, J. Climate, 21, 2473-2590, 2008.

deSzoeke, S. P., Fairall, C. W., Wolfe, D. E., Bariteau, L., and Zuidema, P.: Surface Flux Observations on the Southeastern Tropical Pacific Ocean and Attribution of SST Errors in Coupled Ocean-Atmosphere Models, J. Climate, 23, 4152-4174, 2010.

Garreaud, R. D. and Muñoz, R.: The diurnal cycle in circulation and cloudiness over the subtropical southeast Pacific: A modeling study, J. Climate, 17, 1699-1710, 2004.

Garreaud, R. D. and Muñoz, R.: The low-level jet off the subtropical coast of South America: Structure and variability, Mon. Weather Rev., 133, 2246-2261, 2005.

Geoffroy, O., Brenguier, J.-L., and Sandu, I.: Relationship between drizzle rate, liquid water path and droplet concentration at the scale of a stratocumulus cloud system, Atmos. Chem. Phys., 8, 4641-4654, doi:10.5194/acp-8-4641-2008, 2008.

George, R. C. and Wood, R.: Subseasonal variability of low cloud radiative properties over the southeast Pacific Ocean, Atmos. Chem. Phys., 10, 4047-4063, doi:10.5194/acp-10-4047-2010, 2010.

Hawkins, L. N., Russell, L., Covert, D., Quinn, P., and Bates, T.: Carboxylic acids, sulfates, and organosulfates in processed continental organic aerosol over the Southeast Pacific Ocean during VOCALS-REx 2008, J. Geophys. Res., 107, D13201, doi10.1029/2009JD013276, 2010.

Huneeus, N., Gallardo, L., and Rutllant, J. A.: Offshore transport episodes of anthropogenic sulfur in northern Chile: Potential impact on the stratocumulus cloud deck, Geophys. Res. Lett., 33, L19819, doi:10.1029/2006/GL026921, 2006.

Klein, S. A. and Hartmann, D. L.: The seasonal cycle of low stratiform clouds, J. Climate, 6, 1588-1606, 1993.

Leon, D. C., Wang, Z., and Liu, D.: Climatology of drizzle in marine boundary layer clouds based on 1 year of data from CloudSat and Cloud-Aerosol Lidar and Infrared Pathfinder Satellite Observations (CALIPSO), J. Geophys. Res., 113, D00A14, doi:10.1029/2008JD009835, 2008.

Lohmann, U. and Feichter, J.: Global indirect aerosol effects: a review, Atmos. Chem. Phys., 5, 715-737, doi:10.5194/acp-5-7152005, 2005.

Ma, C. C., Mechoso, C. R., Robertson, A. W., and Arakawa, A.: Peruvian stratus clouds and the tropical Pacific circulation: a cou- pled ocean-atmosphere GCM study, J. Climate, 9, 1635-1645, 1996.

Mechoso, C. R., Robertson, A. W., Barth, N., Davey, M. K., Delecluse, P., Gent, P. R., Ineson, S., Kirtman, B., Latif, M., Le Treut, H., Nagai, T., Neelin, J. D., Philaner, S. G. H., Polcher, J., Schopt, P. S., Stockdale, T., Suarez, M. J., Terray, L., Thual, O., and Tribbia, J. J.: The seasonal cycle over the tropical Pacific in coupled ocean-atmosphere general circulation models, Mon. Weather Rev., 123, 2825-2838, 1995.

Minnis, P., Nguyen, L., Doelling, D. R., Young, D. F., Miller, W. F., and Kratz, D. P.: Rapid calibration of operational and research meteorological satellite imagers, Part I: Evaluation of research satellite visible channels as references, J. Atmos. Ocean. Tech., 19, 1233-1249, 2002.

Minnis, P., Trepte, Q., Sun-Mack, S., Chen, Y., Doelling, D. R., Young, D. F., Spangenberg, D. A., Miller, W. F., Wielicki, B. A., Brown, R., Gibson, S. C., and Geier, E. B.: Cloud detection in non-polar regions for CERES using TRMM VIRS and Terra and Aqua MODIS data, IEEE T. Geosci. Remote, 46, 3857-3884, 2008.

Minnis, P., Sun-Mack, S., Young, D. F., Heck, P., Garber, D., Chen, Y., Spangenberg, D. A., Arduini, R., Trepte, Q., Smith, Jr., W., Ayers, J., Gibson, S. C., Miller, W. F., Chakrapani, V., Takano, Y., Liou, K.-N., and Xie, Y.: CERES Edition-2 cloud property retrievals using TRMM VIRS and Terra and Aqua MODIS data, Part I: Algorithms, IEEE T. Geosci. Remote, p. submitted, 2010.

Muñoz, R., Garreaud, R., and coauthors: Meteorological variability at Paposo, in preparation, 2011.

Painemal, D. and Zuidema, P.: Microphysical variability in southeast Pacific Stratocumulus clouds: synoptic conditions and radiative response, Atmos. Chem. Phys., 10, 6255-6269, doi:10.5194/acp-10-6255-2010, 2010.

Palikonda, R., Minnis, P., Spangenberg, D. A., Khaiyer, M., Nordeen, M. L., Ayers, J., Nguyen, Y., Chan, P. K., Trepte, Q., Chang, F.-L., and Smith Jr., W.: NASA-Langley web-based operational real-time cloud retrieval products from geostationary satellites, Proc. SPIE Asia-Pac. 5th Intl. Symp., Conf. Rem. Sens. Atmos. and Clouds, 6804-72, CD-ROM, 9 pp., 2006.

Pavolonis, M. and Heidinger, A.: Daytime cloud overlap detection from AVHRR and VIIRS, J. Appl. Meteorol., 43, 762-778, 2004.

Rahn, D. A. and Garreaud, R.: Marine boundary layer over the subtropical southeast Pacific during VOCALS-REx - Part 1: Mean structure and diurnal cycle, Atmos. Chem. Phys., 10, 4491-4506, doi:10.5194/acp-10-4491-2010, 2010a.

Rahn, D. A. and Garreaud, R.: Marine boundary layer over the subtropical southeast Pacific during VOCALS-REx - Part 2: Synoptic variability, Atmos. Chem. Phys., 10, 4507-4519, doi:10.5194/acp-10-4507-2010, 2010b.

Rozendaal, M. A., Leovy, C. B., and Klein, S. A.: An observational study of the diurnal cycle of marine stratiform cloud., J. Climate, 8, 1795-1809, 1995.

Savic-Jovcic, V. and Stevens, B.: The structure and mesoscale organization of precipitating stratocumulus, J. Atmos. Sci., 65, 15871605, 2008.

Stevens, B. and Feingold, G.: Untangling aerosol effects on clouds and precipitation in a buffered system, Nature, 461, 607-613, 2009.

Stevens, B., Vali, G., Comstock, K., Wood, R., VanZanten, M., Austin, P. H., Bretherton, C. S., and Lenschow, D. H.: Pock- 
ets of Open Cells (POCs) and Drizzle in Marine Stratocumulus, B. Am. Meteor. Soc., 86, 51-57, 2005.

Stohl, A., Forster, C., Frank, A., Seibert, P., and Wotawa, G.: Technical note: The Lagrangian particle dispersion model FLEXPART version 6.2, Atmos. Chem. Phys., 5, 2461-2474, doi:10.5194/acp-5-2461-2005, 2005.

Tomlinson, J., Li, R., and Collins, D. R.: Physical and chemical properties of the aerosol within the southeastern $\mathrm{Pa}$ cific marine boundary layer, J. Geophys. Res., 111, D12211, doi:10.1029/2006JD007771, 2007.

Toniazzo, T., Mechoso, C. R., Shaffrey, L. C., and Slingo, J. M.: Upper-ocean heat budget and ocean eddy transport in the southeast Pacific in a high-resolution coupled model, Clim. Dyn., 35, 1309-1329, doi:10.1007/s00382-009-0703-8, 2009.

Toniazzo, T., Abel, S. J., Wood, R., Mechoso, C. R., Allen, G., and Shaffrey, L. C.: Large-scale and synoptic meteorology in the South-East Pacific during the observations campaign VOCALSREx in Spring 2008, Atmos. Chem. Phys. Discuss., 11, 225-288, doi:10.5194/acpd-11-225-2011, 2011.

Wang, H. and Feingold, G.: Modeling mesoscale cellular structures and drizzle in marine stratocumulus. Part I: Impact of drizzle on the formation and evolution of open cells, J. Atmos. Sci., 66, 3237-3255, 2009.
Wang, H., Feingold, G., Wood, R., and Kazil, J.: Modelling microphysical and meteorological controls on precipitation and cloud cellular structures in Southeast Pacific stratocumulus, Atmos. Chem. Phys., 10, 6347-6362, doi:10.5194/acp-10-6347-2010, 2010.

Wood, R., Bretherton, C. S., and Hartmann, D. L.: Diurnal cycle of liquid water path over the subtropical and tropical oceans, Geophys. Res. Lett., 29, 2092, doi:10.1029/2002GL015371, 2002.

Wood, R., Comstock, K. K., Bretherton, C. S., Cornish, C., Tomlinson, J., Collins, D. R., and Fairall, C.: Open cellular structure in marine stratocumulus sheets, J. Geophys. Res., 113, D12207, doi:10.1029/2007JD009596, 2008.

Wyant, M. C., Wood, R., Bretherton, C. S., Mechoso, C. R., Bacmeister, J., Balmaseda, M. A., Barrett, B., Codron, F., Earnshaw, P., Fast, J., Hannay, C., Kaiser, J. W., Kitagawa, H., Klein, S. A., Köhler, M., Manganello, J., Pan, H.-L., Sun, F., Wang, S., and Wang, Y.: The PreVOCA experiment: modeling the lower troposphere in the Southeast Pacific, Atmos. Chem. Phys., 10, 4757-4774, doi:10.5194/acp-10-4757-2010, 2010.

Xue, H., Feingold, G., and Stevens, B.: Aerosol effects on clouds, precipitation, and the organization of shallow cumulus convection, J. Atmos. Sci., 65, 392-406, 2008.

Zuidema, P., Painemal, D., de Szoeke, S., and C., F.: Stratocumulus cloud top height estimates and their climatic implications, J. Climate, 22, 4652-4666, 2009. 